\title{
지역축제 콘텐츠품질(CONTSQUAL) 척도 개발 Development of Measurement Standard Scale for Festival contents quality (CONTSQUAL)
}

\author{
맹해영, 장형유 \\ 경상대학교 경영학과 \\ Hae-Yeong Maeng(skydrs@hanmail.net), Hyeong-Yu Jang(jmgt21@gnu.ac.kr)

\section{요약} \\ 본 연구는 지속가능한 축제품질 척도 개발 가운데 축제의 콘텐츠품질 척도를 개발하여 결과변수인 축제 \\ 몰입, 축제만족, 행동의도 간의 영향관계를 실증적으로 검증하였다. 축제 콘텐츠품질의 구성요인은 의례성, \\ 체험성, 전시성, 판매성, 교육성, 경연성, 공연성이다. 척도의 개발의 목적은 우리나라 지역축제가 다양한 축 \\ 제콘텐츠로 구성되어 있고 콘텐츠마다 고유한 특성을 가지고 있어 이를 평가할 수 있는 기준을 마련하여 \\ 고객지향적인 축제콘텐츠를 기획하고 연행하기 위한 것이다. \\ 본 연구에서는 척도를 개발하기 위한 분석의 틀로써 2012년 문화관광축제로 선정된 45개 축제 홈페이지 \\ 에 게시된 콘텐츠 분류명, 행사내용, 행사일정 등을 통찰함으로써 7 개의 구성요인을 도출하였고 후속적 문 \\ 헌연구를 통해 축제 콘텐츠품질 척도를 개발하였고 개발된 척도를 실증분석하기 위해 “금산인삼축제”에 참 \\ 여한 방문객을 표본 집단으로 이용하였다. \\ 분석결과, 축제 콘텐츠품질 구성요인 가운데 체험성, 전시성, 판매성, 경연성, 공연성이 축제몰입에 정 $(+)$ \\ 의 영향을 미치는 것으로 나타났다. 그리고 축제몰입은 축제만족에 정 $(+)$ 의 영향을 미치는 것으로 나타났고 \\ 축제만족 역시 행동의도에 정(+)의 영향을 미치는 것으로 나타났다. \\ 본 연구는 기존의 선행연구들과 달리 우리나라 지역축제의 콘텐츠를 평가하기 위한 척도를 처음으로 개 \\ 발하여 실증분석을 통해 검증하였다. 이로써 축제콘텐츠를 보다 객관적으로 평가하기 위한 세분화된 축제 \\ 품질 측정의 토대를 마련하였다.
}

a 중심어 : | 지역축제 | 콘텐츠품질 | 축제몰입 | 축제만족 | 행동의도 |

\section{Abstract}

Festival contents have played a role as a mediator that connects consumers and producers of the Festivals to express the purpose or theme of those. The successful quality factors to be successively sustainable excellent Festivals include ritual, experience, exhibition, sales, education, competitive, performance. In this study, Festival contents scales, that is named CONTSQUAL, being consisted of seven factors were drawn through the analysis of Cultural Tourism Festival 2012. Festival CONTSQUAL is ritual, experience, exhibition, sales, education, competitive, performance.

The research sample is participants in the "Geumsan Insam Festival". Empirical analysis was carried out for visitors to verify the scales and research model. As a result, among festival CONTSQUAL, all components of qualities affected positively on Festival Flow but ritual and education. Festival flow affected positively on festival satisfaction while festival satisfaction affected positively on behavior intention.

This study not only measured festival quality through the newly developed CONTSQUAL scales underlying sustainable competitive festival, but also built basic foundation for objectively assessing the festival contents quality, which would result in ensure successful local festival.

keyword : | Local Festival | Festival CONTSQUAL | Festival Flow | Festival Satisfaction | Behavior Intention |

접수번호 : \#121126-002

접수일자 : 2012년 11월 26일
심사완료일 : 2012년 12월 11일

교신저자 : 장형유, e-mail : jmgt21@gnu.ac.kr 


\section{I. 서 론}

전통축제는 본래 종교적 상징성과 비일상적 유희성이 유기적으로 결합되어 연행되어 왔지만 현대사회의 축제 는 종교적 상징성 보다는 유희성이 공동체 구성원을 하 나로 묶어내는 촉매제 역할을 하고 있다. 전통축제는 성 스러운 존재나 힘과 만날 수 있게 하는 의사소통 수단으 로 축제가 연행되어 왔으나 현대사회의 축제는 종교적 소통보다는 축제 참여객들 간에 의사소통 수단으로 유 희적인 콘텐츠가 사용되고 있다[1]. Huizinga[2]는 축제 를 “인간의 유희적 본성이 문화적으로 표현된 것이라고 하였으며, 놀이는 비일상적, 비생산적인 것이지만 일상 과 생산을 위해서 필수불가결한 것으로 보고 있다”고 하였다. 현대사회에서 축제의 매력은 "문화와 놀이를 매개로 한 잔치”로서 문화와 놀이를 통해 자신들의 삶 을 풍요롭게 하는 것이다. 그러므로 축제의 경쟁력은 무엇보다도 그 축제의 주제에 맞는 중심콘텐츠을 어떻 게 개발하느냐에 달려 있다. 주제에 잘 부합하는 중심 콘텐츠를 잘 개발하여 대중적인 매력성을 높여 나감으 로써 축제의 가치를 높일 수 있다[3].

축제가 성공하기 위해서는 축제 참여객과 지역주민 이 참여할 수 있는 콘텐츠가 많아야 하고, 동시대인이 면 누구나 느낄 수 있는 감흥이 콘텐츠에 녹아 있어야 한다. 그리고 축제 주제의 중심이 되는 킬러콘텐츠 실 천을 위한 지역주민의 관심과 적극적인 참여가 있어야 하며, 킬러콘텐츠와 주변 콘텐츠와의 유기적 관계도 잘 형성되어야 한다[4]. 그리고 축제참가자들이 정서적 또 는 물리적 매개체인 축제콘텐츠를 통해 재미와 몰입을 느낄 수 있어야 한다. 축제의 콘텐츠는 축제의 목적이 나 주제를 표출하는 매개체로서 축제의 생산자와 소비 자를 연결해 주는 역할을 하고 있으며 축제의 핵심콘텐 츠는 축제를 대표하고 특징적인 주제와 축제의 주된 내 용을 구체화하여 주제성과 정체성을 나타내는 역할을 한다. 핵심콘텐츠가 중요한 이유는 축제 참가자들이 축 제를 쉽게 이해하고 축제의 주제와 주된 내용을 구체화 하여 새로운 브랜드를 생성하고 지역에 미치는 다양한 성과로 인해 성공적인 축제가 될 수 있기 때문에 매우 중요하다고 할 수 있다[5].
결국 성공적이고 지속가능한 지역축제가 되기 위해 서 주제화된 축제콘텐츠의 성공으로 귀결되며, 그 중에 서도 킬러콘텐츠의 중요성과 가치는 참여객의 축제몰 입과 축제만족과 재방문으로 이어지는 성공적인 결과 를 가져오게 된다.

축제콘텐츠의 형식과 유형은 축제의 종류에 따라 매 우 다양하며, Getz[6]는 온타리오축제 콘텐츠를 음악콘 텐츠, 음식콘텐츠, 문화콘텐츠, 레크리에이션콘텐츠, 오 락콘텐츠, 역사콘텐츠, 창의적콘텐츠, 교육콘텐츠, 기타 콘텐츠로 분류하였다. 이경모[7]는 지역축제를 의식콘 텐츠, 전시 및 판매콘텐츠, 교육콘텐츠로 분류하였고, 송재일·손대현[8]은 기획콘텐츠, 공연콘텐츠, 전시콘텐 츠, 체험콘텐츠 등 4 개의 유형으로 구분하였으며 손선 미[9]는 관람콘텐츠, 수동적 참여콘텐츠, 적극적 참여콘 텐츠, 교류콘텐츠, 구매콘텐츠, 시식콘텐츠로 분류하였 다. 이들 선행연구의 축제콘텐츠 분류는 공감하는 바가 있으나 구분의 현실성과 객관성이 확보하지 못한 것으 로 보인다. 그리하여 본 연구에서는 축제 현장성 반영 과 객관성 확보를 위해 45 개 문화관광축제 각각의 홈페 이지에 게시된 콘텐츠별 분류명, 행사내용, 행사일정 등 을 분석하여 축제 콘텐츠품질의 구성요인으로 설정하 였다.

한편, 축제품질에 대한 연구는 기대와 성과 간의 갭 (gap)을 평가하는 PZB[10]의 SERVQUAL을 적용한 지 속적인 연구[11-13]가 진행되어 왔고 축제콘텐츠에 대 한 연구는 일부 연구자[14-16]에 의해 이루어져 왔으나 본 연구자는 축제의 지속가능성을 축제의 기초품질, 콘 텐츠품질, 서비스품질로 3단계로 나누어 지속가능한 축 제의 품질을 연구해 보고자 한다. 이 가운데 본 연구에 서 다루고자 하는 축제의 콘텐츠품질은 축제의 속성에 관한 평가 척도로서 축제의 지속가능성을 핵심적으로 검토하는 과정이 될 것이다. 그리고 본 연구에서는 보 다 과학적이고 합리적인 연구 방법을 토대로 지속가능 한 축제 콘텐츠품질 척도를 개발함과 동시에 지역축제 현장에서 실증적인 평가를 실시하여 개발된 척도의 타 당성을 과학적이고 실무적으로 검증해보고자 한다. 


\section{II. 척도 개발 과정}

\section{1. 척도 개발의 배경}

문화체육관광부가 2009년 새해 업무보고에서 우리나 라에서 연행되는 축제가 1,178 개라고 밝혔다[17]. 이들 축제는 축제의 유형에 따라 다양한 콘텐츠로 구성되어 있으며 각각의 콘텐츠마다 품질 측정기준이 마련되지 않고 있는 실정이다.

\section{표 1. 문화체육관광부 선정 문화관광축제}

\begin{tabular}{|c|c|}
\hline 축제등급 & 축 제 명 \\
\hline 대표 축제 & 강진청자문화제, 진주남강유등축제 \\
\hline 최우수축제 & $\begin{array}{l}\text { 금산인삼축제, 김제지평선축제, 문경찻사발축제, 양양송 } \\
\text { 이축제, 천안홍타령축제, 하동야생차문화축제, 함평나비 } \\
\text { 축제, 화천산천어축제 }\end{array}$ \\
\hline 우수축제 & $\begin{array}{l}\text { 가평자라섬재즈페스티벌, 강경젓갈축제, 광주 } 7080 \text { 충장 } \\
\text { 축제, 남원 춘향제, 담양대나무축제, 부산자갈치축제, 무주 } \\
\text { 반딧불축제, 영동난계국악축제, 이천쌀문화축제, 진도신비 } \\
\text { 의바닷길축제, 풍기인삼축제, 춘천국제마임축제 }\end{array}$ \\
\hline 유망축제 & $\begin{array}{l}\text { 고령대가야체험축제, 광주김치대축제, 괴산고추축제, 대 } \\
\text { 구약령시한방축제, 보성다향제 녹차대축제, 부여서동연 } \\
\text { 꽃축제, 봉화은어축제, 산청지리산한방약초축제, 수원화 } \\
\text { 성문화제, 순창장류축제, 영암왕인문화제, 울산고래축제, } \\
\text { 인천펜타포트축제, 서귀포칠십리축제, 제주정월대보름축 } \\
\text { 제, 창원가고파국화축제, 태백산눈축제, 통영한산대첩축 } \\
\text { 제, 평창효석문화제, 포항불빛축제, 한산모시문화제, 함 } \\
\text { 양산삼축제, 해운대모래축제 }\end{array}$ \\
\hline
\end{tabular}

그리하여 본 연구에서는 축제콘텐츠가 다양하고 우 리나라 축제를 대표한다고 할 수 있는 문화체육관광부 에서 지정한 문화관광축제를 대상으로 연구를 실시하 였다. 축제의 콘텐츠품질 구성요소 도출을 위한 분석의 틀로써 『2012년 문화관광축제』로 선정된 45개 축제 [표 1] 홈페이지에 게시된 콘텐츠 분류명, 행사내용, 행 사일정 등을 분석하여 콘텐츠별로 분류하였다.

\section{2. 문화관광축제 홈페이지 행사내용 의한 구성 요소 도출}

문화관광축제로 지정된 45 개의 축제는 홈페이지를 통해 축제를 홍보하고 있다. 홈페이지에 게시된 메뉴 가운데 행사내용에는 축제의 콘텐츠 분류와 콘텐츠 정 보를 소개하고 있다. 본 연구에서는 이를 토대로 축제 콘텐츠를 분류하여 분석의 틀을 삼았다.

흠페이지를 분류한 결과, 의례성 27 개, 체험성 43 개,
전시성 41 개, 판매성 40 개, 교육성 16 개, 경연성 44 개, 공연성 45 개가 도출되었다[표 2]. 의례성은 특산품 축제 에서 많이 나타났고 문화관광축제에서 주로 나타난 축 제콘텐츠의 구성요소로는 체험성, 전시성, 판매성, 경연 성, 공연성이 핵심요인으로 나타났다. 이 가운데 교육성 은 등장횟수가 다소 낮기는 하지만 축제의 지속 가능성 이나 축제관련 산업의 발전 방향을 제시할 수 있다는 차원에서 중요한 구성요인이라 생각되어 포함시켰다.

표의 분석에 기초하여 본 연구에서는 축제 콘텐츠품 질 구성요인을 의례성, 체험성, 전시성, 판매성, 교육성, 경연성, 공연성 등으로 보고 이러한 개념과 관련된 문 헌연구를 실시하여 축제 콘텐츠품질 구성요인을 이론 적으로 정립했다.

\section{표 2. 문화관광축제 홈페이지 축제콘텐츠 분류}

\begin{tabular}{|c|c|c|c|c|c|c|c|}
\hline 축제명 & 의례성 & 체험성 & 전시성 & 판매성 & 교육성 & 경연성 & 공연성 \\
\hline 강진청자축제 & 0 & 0 & 0 & 0 & 0 & 0 & 0 \\
\hline $\begin{array}{l}\text { 진주남강 } \\
\text { 유등축제 }\end{array}$ & 0 & 0 & 0 & 0 & & 0 & 0 \\
\hline 금산인삼축제 & 0 & 0 & 0 & 0 & 0 & 0 & 0 \\
\hline $\begin{array}{c}\text { 김제지평선 } \\
\text { 축제 }\end{array}$ & 0 & 0 & 0 & 0 & 0 & 0 & 0 \\
\hline $\begin{array}{c}\text { 문경찻사발 } \\
\text { 축제 }\end{array}$ & 0 & 0 & 0 & 0 & 0 & 0 & 0 \\
\hline 양양송이축제 & 0 & 0 & 0 & 0 & & 0 & 0 \\
\hline $\begin{array}{c}\text { 천안홍타령 } \\
\text { 축제 }\end{array}$ & & 0 & & & 0 & 0 & 0 \\
\hline $\begin{array}{c}\text { 하동야생 } \\
\text { 차문화축제 }\end{array}$ & 0 & 0 & 0 & 0 & 0 & 0 & 0 \\
\hline 함평나비축제 & 0 & 0 & 0 & 0 & & 0 & 0 \\
\hline $\begin{array}{c}\text { 화천산천어 } \\
\text { 축제 }\end{array}$ & & 0 & 0 & 0 & 0 & 0 & 0 \\
\hline $\begin{array}{c}\text { 가평자라섬 } \\
\text { 재프페스티벌 }\end{array}$ & & & & & & 0 & 0 \\
\hline 강경젓갈축제 & 0 & 0 & 0 & 0 & & 0 & 0 \\
\hline $\begin{array}{l}\text { 광주7080 } \\
\text { 충장축제 }\end{array}$ & & 0 & 0 & 0 & & 0 & 0 \\
\hline 남원 춘향제 & 0 & 0 & 0 & 0 & 0 & 0 & 0 \\
\hline $\begin{array}{c}\text { 담양대나무 } \\
\text { 축제 }\end{array}$ & & 0 & 0 & 0 & & 0 & 0 \\
\hline $\begin{array}{c}\text { 부산자갈치 } \\
\text { 축제 }\end{array}$ & 0 & 0 & 0 & 0 & & 0 & 0 \\
\hline $\begin{array}{c}\text { 무주반딧불 } \\
\text { 축제 }\end{array}$ & & 0 & 0 & 0 & & 0 & 0 \\
\hline
\end{tabular}




\begin{tabular}{|c|c|c|c|c|c|c|c|}
\hline $\begin{array}{l}\text { 영동난계 } \\
\text { 국악축제 }\end{array}$ & 0 & 0 & 0 & 0 & & 0 & 0 \\
\hline $\begin{array}{c}\text { 이천쌀문화 } \\
\text { 축제 }\end{array}$ & 0 & 0 & 0 & 0 & & 0 & 0 \\
\hline $\begin{array}{l}\text { 진도신비의 } \\
\text { 바닷길축제 }\end{array}$ & 0 & 0 & 0 & 0 & & 0 & 0 \\
\hline 풍기인삼축제 & 0 & 0 & 0 & 0 & 0 & 0 & 0 \\
\hline $\begin{array}{l}\text { 춘천국제 } \\
\text { 마임축제 }\end{array}$ & & 0 & & & & 0 & 0 \\
\hline $\begin{array}{c}\text { 고령대가야 } \\
\text { 체험축제 }\end{array}$ & 0 & 0 & 0 & 0 & 0 & 0 & 0 \\
\hline $\begin{array}{l}\text { 광주김치 } \\
\text { 대축제 }\end{array}$ & & 0 & 0 & 0 & 0 & 0 & 0 \\
\hline 괴산고추축제 & 0 & 0 & 0 & 0 & 0 & 0 & 0 \\
\hline $\begin{array}{c}\text { 대구ㅇㅑㅑㄹㅕㅕㅅㅣ } \\
\text { 한방축제 }\end{array}$ & 0 & 0 & 0 & 0 & & 0 & 0 \\
\hline $\begin{array}{l}\text { 보성다향제 } \\
\text { 녹차대축제 }\end{array}$ & 0 & 0 & 0 & 0 & & 0 & 0 \\
\hline $\begin{array}{l}\text { 부여서동 } \\
\text { 연꽃축제 }\end{array}$ & & 0 & 0 & 0 & & 0 & 0 \\
\hline 봉화은어축제 & & 0 & 0 & 0 & & 0 & 0 \\
\hline $\begin{array}{c}\text { 산청지리산 } \\
\text { 한방약초축제 }\end{array}$ & 0 & 0 & 0 & 0 & 0 & 0 & 0 \\
\hline $\begin{array}{c}\text { 수원화성 } \\
\text { 문화제 }\end{array}$ & & 0 & 0 & 0 & & 0 & 0 \\
\hline 순창장류축제 & & 0 & 0 & 0 & 0 & 0 & 0 \\
\hline $\begin{array}{c}\text { 영암왕인 } \\
\text { 문화제 }\end{array}$ & 0 & 0 & 0 & 0 & & 0 & 0 \\
\hline 울산고래축제 & 0 & 0 & 0 & 0 & 0 & 0 & 0 \\
\hline $\begin{array}{c}\text { 인천펜타포트 } \\
\text { 축제 }\end{array}$ & & & & 0 & & & 0 \\
\hline $\begin{array}{c}\text { 서귀포칠십리 } \\
\text { 축제 }\end{array}$ & & 0 & 0 & 0 & & 0 & 0 \\
\hline $\begin{array}{c}\text { 제주정월 } \\
\text { 대보름축제 }\end{array}$ & 0 & 0 & 0 & 0 & & 0 & 0 \\
\hline $\begin{array}{c}\text { 창원가고파 } \\
\text { 국화축제 }\end{array}$ & & 0 & 0 & 0 & & 0 & 0 \\
\hline 태백산눈축제 & & 0 & 0 & 0 & & 0 & 0 \\
\hline $\begin{array}{c}\text { 통영한산대첩 } \\
\text { 축제 }\end{array}$ & 0 & 0 & 0 & & & 0 & 0 \\
\hline $\begin{array}{c}\text { 평창효석 } \\
\text { 문화제 }\end{array}$ & & 0 & 0 & 0 & & 0 & 0 \\
\hline 포항불빛축제 & & 0 & 0 & 0 & & 0 & 0 \\
\hline $\begin{array}{c}\text { 한산모시 } \\
\text { 문화제 }\end{array}$ & 0 & 0 & 0 & 0 & & 0 & 0 \\
\hline 함양산삼축제 & 0 & 0 & 0 & 0 & 0 & 0 & 0 \\
\hline $\begin{array}{c}\text { 해운대모래 } \\
\text { 축제 }\end{array}$ & & 0 & 0 & & & 0 & 0 \\
\hline 계 & 27 & 43 & 41 & 40 & 16 & 44 & 45 \\
\hline
\end{tabular}

\section{3. 축제 콘텐츠품질 구성요소의 개념}

\section{1 의례성}

전통사회에서 축제는 종교적 의식이 중요한 토대가 되어 왔다. 비록 이것이 현대축제에 와서 실질적인 의 미를 가지고 있지는 않는다 하더라도 축제를 이해하는 데 있어서 고려해야 하는 측면인 것은 분명하다. 축제 에서 의례는 성스럽고 궁극적인 가치와 연결되기 때문 에 강력한 사회통합력을 가지고 있을 뿐만 아니라 축제 에 사용되는 특정한 복장이나 가면 등 의례적인 특징을 드러내는 요소들을 포함하면서 의식이나 행렬, 음악, 춤 등이 해당사회의 의례적인 상황들과 연결된 신성한 놀 이로 진화하게 되었다[3].

Catherine Bell[18]은 의례의 이해에서 "의례는 '우리 들'과 어떤 '타자들' 사이에 일련의 관계를 맺어주는 방 식으로 그 타자는 절대자이거나 숭배자 일 수도 있다" 고 하였다. 기능-구조주의자들은 의례가 지닌 "사회적' 작동 방식을 탐구하였는데 의례는 인간 공동체를 수립 하는 사회적 유대를 형성하고 유지하는 것, 지식과 경 험에 대한 공동의 가치들과 공동의 범주들을 무의식적 으로 충당시켜 줌으로써 개개인을 사회화 하는 것, 사 회적 갈등을 일정한 방향으로 유도하여 해소하는 것, 공동체의 삶을 뒷받침하는 사회적이고 개념적인 구조 들을 주기적으로 재생하거나 변형하는 것 등이 기능구조주의자들이 탐구한 것들이다.

이를 바탕으로 본 연구에서 정의한 의례성은 “축제를 통하여 축제 참여객들이 소속의 옥구와 공동체 의식을 함양하고 심리적 안정감과 정화감을 느끼는 정도”이다.

\section{2 체험성}

전통축제에서 축제콘텐츠는 공동체 구성원 모두가 참여해야만 축제가 완성되는 구조였으나 현대사회의 축제는 축제 참여객들이 일상적인 생활에서 경험할 수 없는 여가적 혹은 사회문화적 체험의 기회를 축제가 제 공하여야 한다.

Pierce[19]는 축제 참여객이 축제에서 체험하고자 하 는 요인을 일탈감, 대인교류감, 모험감, 지적체험, 이색 체험, 창의적 체험으로 구분하였다. 일탈감은 반복되는 일상으로부터 탈출하여 느끼는 새로운 체험이고, 대인 
교류감은 축제 체험을 통하여 축제 참여객들과 직, 간 접적인 관계를 통해 이루어지는 사회적 체험이다. 그리 고 모험감은 스릴 있는 신체활동에 도전하는 체험이고, 이색체험은 기이한 현상, 혹은 이문화적 요소에 대해 기억에 남을 만한 체험을 의미한다. 지적체험은 인간의 지적 옥구를 충족시키기 위한 학습체험이고, 창의적 체 험은 예술, 문화 등 창조적인 활동에 참여하거나 작품 활동을 하는 것을 말한다. 한편, Schmitt[20]는 체험을 보다 심층적인 방법으로 5 가지를 분류하였는데, 지각적 인 체험(sence), 정서적인 체험(feel), 창조적이고 인지 적인 체험(think), 행동적이고 라이프스타일과 관련된 경험(act), 준거집단과 문화 등에 의해 야기되는 사회적 정체성의 체험(realte)으로 분류하였다.

이를 바탕으로 본 연구에서 정의한 체험성은 “축제를 통하여 일탈감과 대인교류감, 모험감을 느끼고 지적 욕 구와 이색적이고 창조적인 활동에 참여하는 정도”이다.

\section{3 전시성}

축제에서 전시는 축제와 관련된 다양한 정보를 제공 하는 공간으로 축제 참여객이 직접 대면할 수 있으며, 축제 상품의 촉진 수단으로 사용되기도 하고 축제 참여 객들에게 축제 이미지를 반영하여 잠재적으로 축제와 축제 참여객을 연결시키는 중요한 역할을 한다. 현대축 제는 축제 참여객들에게 효과적인 커뮤니케이션 수단 으로 다양한 전시콘텐츠를 보여주고 있다.

축제의 전시공간은 쾌적한 관람을 위한 부스 배치와 일목요연한 주제 표현, 그리고 심리적 안정감을 느낄 수 있는 동선설계가 필요하다. 그리고 전시는 축제 참여객 으로 하여금 생생하고 풍부한 자료를 제공하여야 하고, 관람객으로 하여금 신기함과 호기심을 느끼게 하며 환 상적, 감정적 동기를 불러 일으켜야 한다[21]. 이정학 등 [22]은 전시회의 서비스 품질은 전시장 품질, 안내품질, 홍보품질 등 세 가지 요인으로 구분하고 있는데 우선 전 시장 품질 요인으로는 통신시설, 실내장식, 내부동선 등 의 세부 요인이 있고, 안내품질로는 편의시설, 표지판, 안내책자, 부스시설, 홍보품질에는 행사 사전 설명의 내 용일치성, 시간준수, 정확한 공지, 홈페이지, 참관객 유 치활동 등을 세부 요인으로 구분하고 있다.
이를 바탕으로 본 연구에서 정의한 전시성은 "축제전 시장의 안정감 있는 동선을 따라 쾌적한 관람을 할 수 있으며, 생생한 자료를 통해 신기함과 호기심을 느끼고 환상적, 감정적 동기를 불러일으키는 정도”이다.

\section{4 판매성}

전통사회에서 축제는 공동체 구성원들만의 의례나 유희였으므로 축제 운영을 위한 경비를 내부에서 조달 할 수 있었으나 현대사회의 축제는 유희성이 강한 스펙 터클한 규모의 축제를 운영하게 되고 대부분 축제운영 경비를 국가나 지방정부에서 지원을 받고 있는 실정이 기 때문에 축제에서 생산성이 강조되고 있다. 축제에서 부가가치 창출을 위해 축제 콘텐츠 관람의 유료화도 하 나의 방편이지만 지역축제에서 부가가치 창출을 위한 가장 적절한 방법은 해당지역의 고유음식, 전통물품, 농 특산물 또는 캐릭터 상품 등을 통한 수익성과 시장성을 고려해야 한다. 특히, 고유음식이나 전통물품의 경우에 는 그 속에 지역고유의 정신적 자산이라고 할 수 있는 문화가 배어있기 때문에 문화공유의 의미가 있다. 이와 같이 축제에서 해당지역과 관련된 물품을 구매하는 쇼 핑은 축제의 판매콘텐츠로서 축제 참여객에게 매우 유 용한 체험과 만족을 줄 것이다. 이를 위해서는 상품 판 매를 효과적으로 하기 위해 축제 참여객의 소비심리를 자극하는 여러 가지 기능적, 심리적 장치가 필요하다.

Martineau[23]는 점포의 이미지를 기능적 속성과 심 리적 속성으로 구분하였는데, 기능적 속성이란 취급제 품, 가격범위, 신용정책, 레이아웃과 같은 속성이고, 심 리적 속성은 친근감, 귀속감, 흥미감과 같은 감정이라고 하였다. Kotler[24]에 의하면 분위기란 일반적으로 주위 환경의 특성을 나타내는 개념으로서 점포분위기는 구 매자의 구매확률을 높이는 특별한 정서적 효과를 창출 하기 위해 구매환경을 디자인하는 노력이라고 보았다.

이를 바탕으로 본 연구에서 정의한 판매성은 "좋은 점포분위기에서 구매력이 있는 축제 상품을 레이아웃 하여 축제 참여객의 흥미를 돋우고 친근감이 있게 소비 자를 맞이하는 정도”이다. 


\section{5 교육성}

축제에서 교육콘텐츠는 축제와 관련된 세미나, 토론 회 등이고, 지역특산물과 관련된 것으로 생산성 향상이 나 상품화를 위한 기술 교육, 판매를 위한 마케팅 교육 등이 있다. 이러한 교육콘텐츠의 품질은 교육콘텐츠 제 공자와 수강자 간에 유·무형의 지식의 전달을 통해 정 신적·물질적 만족을 실현 시켜주는 일체의 활동으로 정 의할 수 있다. 이와 같이 축제에서 교육콘텐츠는 축제 의 방향 설정이나 지속가능성을 논의할 수 있을 뿐만 아니라 지역생산품의 생산성 향상, 마케팅 방향 설정 등 각 분야의 전문가들과 논의할 수 있는 장을 마련하 는데 큰 의의가 있다.

Martensen, Gronholdt, Eskilden \& Kristensen[25]은 교육의 품질은 하드웨어와 휴먼웨어로 나누고 있는데 그 가운데 소프트웨어적인 교육의 품질을 통해 교육콘 텐츠의 구성요인은 강의 내용, 강의 적절, 강의 수준과 같은 교육콘텐츠와 강사의 의사소통, 강사와 수강생의 열의를 내세울 수 있다.

이를 바탕으로 본 연구에서 정의한 교육성은 "강의의 수준과 강사의 의사소통, 강의의 적절성과 수강생이 강 의에 충실한 정도”이다.

\section{6 경연성}

전통축제에서는 경쟁을 통하여 공동체 구성원들 간 에 유대와 결속을 다지는 수단으로 사용되었지만 현대 사회의 축제는 경쟁을 통하여 보다 우수함을 입증하는 잣대로 사용되고 있다.

Roger Callois[26]는 경쟁의 우위를 따지는 아곤(agon) 이 인간의 놀이의 체계 속에 자리 잡고 있다고 하였다. 아 곤은 정해진 규칙과 의지가 동시에 작용하는 것으로 규칙 은 힘을 공정하게 발휘하도록 강제할 뿐만 아니라 승리자 의 우월성을 확실하게 하는 기능을 한다. Johnson \& Johnson[27]은 “경쟁은 참가자가 유일하게 혹은 극소수만 이 획득할 수 있는 목표를 성취하기 위해 서로에 대항하여 움직일 때 존재한다” 고 하였다. Helmreich, Beane, Lucker, $\&$ Spence[28]는 "경쟁심은 어떤 상황에 있어서 개인 간 이 기고자 하는 열망이다”라고 하였다. 이와 같은 경쟁은 인 간의 본성을 포함한 자연계에 본래부터 존재하는 고유한
특성이고, 개인이 최선을 다하도록 동기를 부여하는 것이 며 경쟁을 통하여 최고를 이끌어 내게 되어 재미를 느낄 수 있다.

이를 바탕으로 본 연구에서 정의한 경연성은 “정해진 규칙 안에서 참여자의 의지가 작동하여 상호 긴장 상황에서 최선 을 다하여 승리를 이끌어 내고자 하는 열망의 정도”이다.

\section{7 공연성}

전통축제에서 특정한 복장이나 장식, 가면 등 의례적 인 특징을 드러내는 형상으로 제단의 공간에서 절대자나 숭배자를 감화시키기 위해 의식이나 행렬, 음악, 춤 등으 로 공연을 하였다. 그러나 현대사회의 축제 공연은 문화 적 공감대를 형성하여 축제 참여객을 유인하고 상호 교 감하는 수단으로 다양한 공연콘텐츠가 연행되고 있다.

표 3. 축제의 콘텐츠품질 구성요소에 관한 명칭과 개념 및 관련 연구

\begin{tabular}{|c|c|c|}
\hline 구성요소 & 개념 정의 & 관련연구 \\
\hline 의례성 & $\begin{array}{l}\text { 축제를 통하여 축제 참여객들이 소속의 욕 } \\
\text { 구와 공동체 의식을 함양하고 심리적 안정 } \\
\text { 감과 정화감을 느끼는 정도 }\end{array}$ & $\begin{array}{l}\text { Catherine } \\
\text { Bell, } 1997\end{array}$ \\
\hline 체험성 & $\begin{array}{l}\text { 축제를 통하여 일탈감과 대인교류감, 모험 } \\
\text { 감을 느끼고 지적 욕구와 이색적이고 창조 } \\
\text { 적인 활동에 참여하는 정도 }\end{array}$ & $\begin{array}{l}\text { Pierce, } 1980 \\
\text { Schmitt, } 1999\end{array}$ \\
\hline 전시성 & $\begin{array}{l}\text { 축제전시장의 안정감 있는 동선을 따라 쾌 } \\
\text { 적한 관람을 할 수 있으며, 생생한 자료를 } \\
\text { 통해 신기함과 호기심을 느끼고 환상적, 감 } \\
\text { 정적 동기를 불러일으키는 정도 }\end{array}$ & $\begin{array}{l}\text { Konikow, } \\
1985\end{array}$ \\
\hline 판매성 & $\begin{array}{l}\text { 좋은 점포분위기에서 구매력이 있는 축제 } \\
\text { 상품을 레이아웃하여 축제 참여갤의 흥미를 } \\
\text { 도두고 친근감이 있게 소비자를 맞이하는 } \\
\text { 정도 }\end{array}$ & $\begin{array}{l}\text { Martineau, } \\
1958\end{array}$ \\
\hline 교육성 & $\begin{array}{l}\text { 강의의 수준과 강사의 의사소통, 강의의 적 } \\
\text { 절성과 수강생이 강의에 충실한 정도 }\end{array}$ & $\begin{array}{l}\text { Martensen, } \\
\text { et al., } 2000\end{array}$ \\
\hline 경연성 & $\begin{array}{l}\text { 정해진 규칙 안에서 참여자의 의지가 작동 } \\
\text { 하여 상호 긴장 상황에서 최선을 다하여 승 } \\
\text { 리를 이끌어 내고자 하는 열망의 정도 }\end{array}$ & $\begin{array}{l}\text { Helmreich, } \\
\text { et al., } 1978\end{array}$ \\
\hline 공연성 & $\begin{array}{l}\text { 축제 무대에서 공연되는 공연물의 우수성과 } \\
\text { 명성, 즐거움, 기분전환, 생생한 체험, 정신 } \\
\text { 적 만족감, 문화적 생활수준의 향상을 느낄 } \\
\text { 우 있는 정도 }\end{array}$ & $\begin{array}{l}\text { 권혁인 등, } \\
2011 \\
\text { 조인희 등, } \\
2009\end{array}$ \\
\hline
\end{tabular}

공연예술이란 음악, 무용, 곡예, 댄스, 쇼 등 예술적 관람물의 실연(demonstration)에 의하여 공중에게 관람 하도록 하는 행위를 말한다[29]. 공연은 청중 없이는 존 재하지 않으며 공연을 성공적으로 수행하기 위해서는 청중의 욕구와 동기를 이해하지 않으면 안된다[30]. 축 
제 참여객들은 공연관람을 통하여 공연물의 우수성, 공 연작품의 명성[31], 즐거움, 기분전환, 생생한 체험, 정 신적 만족감, 문화적 생활수준의 향상을 느낄 수 있어 야 한다[32].

이를 바탕으로 본 연구에서 정의한 공연성은 “축제 무대에서 공연되는 공연물의 우수성과 명성, 즐거움, 기 분전환, 생생한 체험, 정신적 만족감, 문화적 생활수준 의 향상을 느낄 수 있는 정도”이다.

이상에서 정의한 축제 콘텐츠품질 구성요인의 개념 화 정의와 그러한 정의와 관련한 핵심 연구를 요약하면 [표 3]과 같다.

\section{4. 축제몰입, 축제만족, 행동의도 구성요소의 개념}

본 연구에서 축제 콘텐츠품질과 직접 연관된 변수로 축제몰입을 도입하게 된 것은 축제 콘텐츠가 축제의 목 적이나 주제를 표출하는 매개체로서 축제 생산자와 축 제 소비자를 연결해 주고 축제 소비자인 참여객이 축제 콘텐츠에 몰입하게 될 때 축제의 매력을 느낄 수 있기 때문이다. 이훈[33]은 몰입이 축제 체험 속성 중 놀이성 이 갖고 있는 중요한 부분이라고 언급하면서, 방문객들 의 적극적인 참여로 몰입의 즐거움이 야기 될 수 있다고 하였다. 이와 같이 참여객이 축제에 몰입하게 되면 축제 에 만족하게 되고 만족하면 행동의도를 보이게 된다.

\section{1 축제몰입}

몰입(flow)은 사람들이 어떤 활동 자체에 몰두하여 경험하게 되는 상태로써 의식이나 지각을 한 곳에 집중 하게 되고, 자신이 집중하고 있는 일이나 활동과 무관 한 사고나 생각을 하지 않게 되며 심리적으로 즐거움과 행복감을 느끼게 되는 것을 말한다[34]. 박근수[35]는 "몰입을 통해서 최종적으로 최상의 경험이라고 할 수 있는 즐거움과 행복감, 만족감 등이 수반되고 불안과 같은 부정적 정서가 없는 상태에 이르게 된다는 사실에 덧붙여 몰입은 명확한 목표와 피드백에 대한 반응의 하 나로서 도전 수준과 기술 수준의 균형이 이루어질 때 경험하게 되는 심리적 현상이며, 주어진 과제에 대한 완전한 집중, 활동의 자동적 수행, 자의식의 상실, 시간 감각의 왜곡, 환경에 대한 통제감 등이 발생하게 된다
는 사실이다"라고 하였다.

이를 바탕으로 본 연구에서 정의한 축제몰입은 "축제 콘텐츠의 자발적 참여와 자의식 상실, 환경의 통제감, 체험과제의 수준과 시간감각의 왜곡 등의 정도”이다.

\section{2 축제만족}

축제 참여객이 축제의 품질 경험을 통해 인식하는 축 제만족은 유·무형의 요인에 의해 영향을 받는다. 축제 만족에 가장 큰 영향을 미치는 것으로는 축제 속성에 대한 경험인 축제 콘텐츠품질이 가장 중요한 결정요인 이다.

축제만족은 축제품질에 노출된 후 마음의 감정 상태 를 나타내며, 이러한 축제만족은 참여객의 사회-심리적 인 상태(기분, 성향, 필요 등)와 외부적인 요인(축제환 경, 축제콘텐츠, 축제공급자와 축제소비자의 상호작용 등)에 의해 영향을 받는다[36]. 축제만족은 축제의 지속 가능성을 검증하고 방향을 설정하는데 밀접한 관계가 있고 참여객의 행동의도에 중요한 요인이 될 수 있기 때문이다[37]. 김선희[38]는 “축제에서 제공하는 축제상 품 및 서비스, 공연, 프로그램 경험 등의 성과에 따른 전 체적인 평가를 의미하며, 기대한 것보다 그 이상의 경 험을 했으면 축제에 대해 만족한다”고 하였다.

이를 바탕으로 본 연구에서 정의한 축제만족은 "축제 내용에 대한 유익성과 편의시설, 홍보안내, 쇼핑과 음 식, 축제운영과 서비스의 만족의 정도”이다.

\section{3 행동의도}

축제에 있어서 행동의도는 축제 경험의 주관적 판단 이 후에 축제 참가에 대한 평가적인 의미로 결정되는 요인이 며 다음 축제에 대한 참여객의 구체적인 반응을 포함하고 있어 고객확보와 축제 촉진의 중요한 변수가 된다.

오선영·강해상[39]은 축제에 있어서 행동의도는 "축 제 참여에 의한 정서적 반응에 대한 후속심리에 의한 행동으로서 추천의도와 재방문의도로 정의” 하였다. 하 광수·한범수[40]는 "전반적 관광만족과 함께 재방문의 도와 긍정적 구전의도가 관광경험과 후속의 심리적 변 수”라고 정의하였다.

이를 바탕으로 본 연구에서 정의한 행동의도는 “축제 
참여에 의한 정서적 반응에 대한 후속심리에 의한 행동 으로 축제의 재방문, 추천, 긍정적 구전과 우선적 참여 의 정도"이다.

표 4. 축제몰입, 축제만족, 행동의도 구성요인에 관한 명칭 과 개념 및 관련 연구

\begin{tabular}{|l|l|c|}
\hline 구성 요인 & \multicolumn{1}{|c|}{ 개념 정의 } & 관련 연구 \\
\hline \multirow{3}{*}{ 축제 몰입 } & $\begin{array}{l}\text { 축제콘텐츠의 자발적 참여와 자의식 상실, } \\
\text { 환경의 통제감, 체험과제의 수준과 시간감 } \\
\text { 각의 왜곡 등의 정도 }\end{array}$ & $\begin{array}{c}\text { 박근수, } \\
2006\end{array}$ \\
\hline \multirow{3}{*}{ 축제 만족 } & $\begin{array}{l}\text { 축제내용에 대한 유익성과 편의시설, ㅎㅗㅗㅂㅗ } \\
\text { 안내, 쇼핑과 음식, 축제운영과 서비스의 } \\
\text { 만족의 정도 }\end{array}$ & $\begin{array}{c}\text { 김선희, } \\
2007\end{array}$ \\
\hline \multirow{2}{*}{ 행동 의도 } & $\begin{array}{l}\text { 축제 참여에 의한 정서적 반응에 대한 후 } \\
\text { 속심리에 의한 행동으로 축제의 재방문, } \\
\text { 추천, 긍정적 구전과 우선적 참여의 정도 }\end{array}$ & $\begin{array}{c}\text { 오선영 } \\
\text { 강해상, } \\
2011\end{array}$ \\
\hline
\end{tabular}

이상에서 정의한 축제 콘텐츠품질과 직접 연관된 구 성요인의 개념화 정의와 그러한 정의와 관련한 핵심 연 구를 요약하면 [표 4]과 같다.

\section{5. 축제 콘텐츠품질 및 축제몰입, 축제만족, 행동 의도 구성요소 개념 정의 이해도 조사}

본 연구에서 도출한 축제의 콘텐츠품질 구성요인에 관한 명칭과 개념을 이해하는 관점에서 문제점 여부를 확인하기 위해 2012년 9월 10일 진주시 소재 G대학교 3 학년 학생 64 명(남자 28명, 여자 36명)을 대상으로 이 해도에 관한 설문조사를 실시하였다[표 5].

표 5. 축제 콘텐츠품질 및 축제몰입, 축제만족, 행동의도 개념정의 이해도 조사

\begin{tabular}{|c|l|}
\hline 조사대상 & G대학교 3학년 64명 (남자 28명, 여자 36명) \\
\hline 표본추출방법 & 편의추출방법 \\
\hline 조사방법 & 설문조사 \\
\hline 조사일시 & 2012. 9. 10 \\
\hline
\end{tabular}

설문내용은 [표 3][표 4]의 내용과 같이 “의례성: 축제 를 통하여 축제 참여객들이 소속의 욕구와 공동체 의식 을 함양하고 심리적 안정감과 정화감을 느끼는 정도”의 개념이 이해가 되는가라는 질문으로 7 개의 축제 콘텐 츠품질 구성요인과 결과변수인 3 개의 개념에 대하여
"확실히 이해된다, 대략적으로 이해된다, 이해 안된다" 로 개념정의에 관한 이해도 조사를 실시하였다.

조사결과, 의례성, 체험성, 전시성, 판매성, 공연성, 축 제몰입, 축제만족, 행동의도에 대해서 '확실히 이해된 다'는 $90 \%$ 이상의 높은 이해도를 나타내었고 경연성은 $84.4 \%$ 로 '대략적으로 이해된다'라는 의사표시를 하였 다. 그러나 교육성에 대해서는 $75 \%$ 정도가 '대략적으로 이해된다'고 하였지만 교육성은 축제의 지속가능성과 축제와 관련된 산업의 발전방향에 대한 요소이므로 본 연구에서 채택하게 되었다. 그리고 결과변수인 축제만 족과 행동의도는 $90 \%$ 이상의 높은 이해도를 나타내었 고 축제만족은 $87.5 \%$ 로 '대략적으로 이해된다'라는 의 사표시를 하였다[표 6].

표 6. 축제 콘텐츠품질 및 축제몰입, 축제만족, 행동의도 개념정의 이해도 조사 결과

\begin{tabular}{|c|c|c|c|c|}
\hline \multirow{2}{*}{$\begin{array}{c}\text { 구성 } \\
\text { 요소 }\end{array}$} & $\begin{array}{c}\mid 3 \\
\text { 확실히 } \\
\text { 이해된대(\%) }\end{array}$ & $\begin{array}{c}|c| \\
\text { 대략적으로 } \\
\text { 이해된다 } \%)\end{array}$ & $\begin{array}{c}\text { 이해 안된다 } \\
(\%)\end{array}$ & $\begin{array}{c}\text { 인원 } \\
(\%)\end{array}$ \\
\hline 의례성 & $16(25.0)$ & $42(65.6)$ & $6(9.4)$ & $64(100)$ \\
\hline 체험성 & $40(62.5)$ & $24(37.5)$ & - & $64(100)$ \\
\hline 전시성 & $48(75.0)$ & $14(21.9)$ & $2(3.1)$ & $64(100)$ \\
\hline 판매성 & $40(62.5)$ & $20(31.3)$ & $4(6.3)$ & $64(100)$ \\
\hline 교육성 & $26(40.6)$ & $22(34.4)$ & $16(25.0)$ & $64(100)$ \\
\hline 경연성 & $26(40.6)$ & $28(43.8)$ & $10(15.6)$ & $64(100)$ \\
\hline 공연성 & $48(75.0)$ & $14(21.9)$ & $2(3.1)$ & $64(100)$ \\
\hline 축제 몰입 & $30(46.9)$ & $26(40.6)$ & $8(12.5)$ & $64(100)$ \\
\hline 축제 만족 & $48(75.0)$ & $16(25.0)$ & - & $64(100)$ \\
\hline 행동 의도 & $32(50.0)$ & $30(46.9)$ & $2(3.1)$ & $64(100)$ \\
\hline
\end{tabular}

\section{III. 척도 검증의 연구 방법}

\section{1. 연구모형 및 가설 설정}

\section{1 연구모형}

본 연구는 축제의 콘텐츠품질의 구성요인을 의례성, 체험성, 전시성, 판매성, 교육성, 경연성, 공연성으로 구 분하여 축제몰입 간의 영향관계에 대해 검증하고, 축제 
몰입과 축제만족, 축제만족과 행동의도 간의 관계에 대 해 검증하고자 한다. 본 연구의 콘텐츠품질의 구성요인 은 문화관광축제로 선정된 지역축제의 홈페이지의 행 사일정과 내용을 검색하여 세부내용을 검토한 후 콘텐 츠 분류에 의해 구성요인 7개를 도출하였다. 도출된 7 개의 구성요인을 문헌연구를 통하여 개념적 정의를 내 린 다음 개념에 대한 이해도 조사를 실시하여 이를 근 거로 [그림 1]과 같이 개념적인 연구모형을 도출하였다.

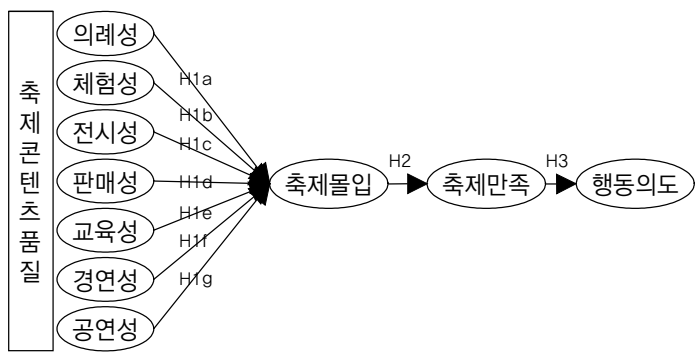

그림 1. 연구 모형

\section{2 가설의 설정}

(1) 축제 콘텐츠품질과 축제몰입의 관계

축제의 콘텐츠는 축제를 성공적으로 연행하게 위한 정서적 또는 물리적 매개체로서 축제 생산자와 소비자 를 연결해주는 장치이다. 축제가 성공적으로 연행되기 위해서는 소속의 욕구와 공동체 의식을 함양하는 의례 와 일탈감, 지적욕구, 이색적인 창조활동에 참여할 수 있는 체험을 할 수 있어야 하며 생동감 있는 전시물을 통해 신기함과 호기심을 느낄 수 있는 전시를 통해 감 정적 동기를 불러일으켜야 한다. 그리고 구매력이 있는 축제상품을 구매할 수 있어야 하고 축제나 축제관련 산 업의 발전을 위한 세미나 개최 등 교육이 이루어져야 하며 여러 가지 경연을 통해 축제의 재미를 느낄 수 있 어야 하고 공연을 통하여 문화적 공감대를 형성하여 참 여객 간에 상호 교감하며 문화적 욕구를 충족하는 계기 가 되어야 한다.

축제 참여객들이 축제에 몰입하기 위해서는 축제콘 텐츠의 자발적으로 참여하고 이를 통해 자의식 상실, 환경의 통제감, 체험과제의 수준과 시간감각의 왜곡 등 을 경험하여야 한다. 즉, 축제몰입(Festival flow)은 축
제의 콘텐츠품질의 구성요인을 통해 형성된다고 볼 수 있다. 축제의 참여객이 의례를 통해 공동체의식을 함양 하고 체험과 전시를 통해 감정적 동기를 불러일으키며 구매력이 있는 축제상품 구입, 교육을 통한 지식 전달, 경연과 공연을 통해 축제의 재미를 느끼고 문화적 욕구 를 충족한다는 전제하에 다음과 같이 축제의 콘텐츠품 질과 축제몰입 간에 가설을 설정하였다.

$\mathrm{H1}$ : 축제의 콘텐츠품질은 축제몰입에 정(+)의 영향 을 미칠 것이다.

$\mathrm{Hla}$ : 의례성은 축제몰입에 정 $(+)$ 의 영향을 미칠 것이다.

$\mathrm{Hlb}$ : 체험성은 축제몰입에 정(+)의 영향을 미칠 것이다.

$\mathrm{H1c}$ : 전시성은 축제몰입에 정 $(+)$ 의 영향을 미칠 것이다.

$\mathrm{Hld}$ : 판매성은 축제몰입에 정 $(+)$ 의 영향을 미칠 것이다.

$\mathrm{Hle}$ : 교육성은 축제몰입에 정 $(+)$ 의 영향을 미칠 것이다.

$\mathrm{H1f}$ : 경연성은 축제몰입에 정 $(+)$ 의 영향을 미칠 것이다.

$\mathrm{Hlg}$ : 공연성은 축제몰입에 정 $(+)$ 의 영향을 미칠 것이다.

이에 본 연구에서 새로 개발된 축제 콘텐츠품질과 축 제몰입과의 관계를 바탕으로 축제 콘텐츠품질의 실행 요인인 의례성, 체험성, 전시성, 판매성, 교육성, 경연성, 공연성이 축제몰입에 어떠한 영향을 미치는지를 실증 적으로 검증하고자 한다.

(2) 축제몰입과 축제만족의 관계

축제에 참여한 관광객들의 만족은 "특정 여가 활동 후 갖게 되는 방문자의 총체적 감정상태”[41]라고 하였 다. 즉, 축제 만족도는 “축제에서 제공하는 축제상품 및 서비스, 공연, 프로그램 경험 등의 성과에 따른 전체적 인 평가"를 의미하며, 기대한 것보다 그 이상의 경험을 했으면 축제에 대해 만족하다고 볼 수 있다. 안대희·이 
낙귀[42]는 축제 참여객의 축제몰입은 축제만족을 증진 시키고 권태감을 줄여준다고 하였으며 축제몰입은 축 제만족의 선행요인으로 선행연구에 대한 검증하여 유 의한 결과를 도출하였다. 강순화[43]는 축제 관여도에 서 고몰입 그룹과 저몰입 그룹 간에 축제만족도 차이 검증에서 고몰입 그룹이 만족도가 높다는 유의한 연구 결과를 내놓았다. 박정익·이미혜[44]는 축제 체험콘텐 츠에 대한 몰입이 만족에 미치는 영향관계를 연구한 결 과, 몰입과 만족은 깊은 상관관계를 가지고 있으며 몰 입과 만족이 재방문의도에도 영향을 미친다고 하였다. 이와 같은 선행연구를 바탕으로 축제몰입과 축제만 족간의 가설을 설정하였다.

$\mathrm{H} 2$ : 축제몰입은 축제만족에 정 $(+)$ 의 영향을 미칠 것 이다.

이에 본 연구에서 이와 같은 선행연구의 몰입이론을 확장하여 정의 한 축제몰입과 축제만족과의 관계를 바 탕으로 축제몰입이 축제만족에 어떠한 영향을 미치는 지를 실증적으로 검증하고자 한다.

(3) 축제만족과 행동의도의 관계

축제 품질을 경험한 참여객의 축제만족과 행동의도 에 관심을 갖는 이유는 축제 공급자가 향후 축제 소비 자의 행동 변화에 대한 예측의 단서가 되기 때문이다. 그러므로 축제의 만족과 행동의도에 대한 연구는 가장 많이 연구되고 있는 분야이다. 특히, 축제 콘텐츠품질은 축제의 속성에 대한 축제 참여객들의 반응이므로 축제 평가의 핵심요인이라 할 수 있다.

민양기[45]는 축제의 지각된 품질이 지각된 만족에 영향을 미치며 지각된 만족은 재방문 의도, 긍정적 구 전에 영향을 미친다고 하였다. 허중욱·박선희[46]는 축 제 방문자의 만족과 행동의도 간의 연구에서 축제방문 자의 만족도는 재방문 의도에 영향을 미친다는 결과를 축제 방문자 하위 요인 가운데 프로그램 만족도, 서비 스 만족도, 편의시설 만족도 등은 재방문 의도에 유의 한 영향을 미친다는 결과를 제시하였다.

이와 같은 선행연구를 바탕으로 축제만족과 행동의
도 간의 가설을 설정하였다.

$\mathrm{H} 3$ : 축제만족은 행동의도에 정 $(+)$ 의 영향을 미칠 것 이다.

이에 본 연구에서 이와 같은 선행연구들의 만족도를 통해 정의 한 축제만족과 행동의도의 관계를 바탕으로 축제만족이 행동의도에 어떠한 영향을 미치는지를 실 증적으로 검증하고자 한다.

\section{2. 조사 설계}

\section{1 자료수집 및 분석방법}

본 연구에서 개발한 축제 콘텐츠품질 척도를 바탕으 로 설정된 연구가설을 검증하기 위하여 2012년 문화관 광축제 최우수축제로 지정된 “금산인삼축제”에서 축제 에 참여한 방문객을 대상으로 자기기입식 설문조사를 실시하였다.

실증 연구에 앞서 본 연구에서 이론적 배경을 바탕으 로 개발된 설문지에 기초하여 G대학교 경영학과 대학 생을 대상으로 1 차 예비조사를 실시하였다. 측정문항의 신뢰도와 타당성을 검토한 후 측정문항을 순화하는 과 정을 거쳐 예비검증에서 나타난 문제점을 순화하였다. 그 후 $\mathrm{K}$ 대학교 관광학과 대학생을 대상으로 2 차 예비 조사를 실시하고 신뢰도 분석과 요인분석을 통해 2 차 예비검증을 실시하였다.

본 조사는 1,2 차 예비조사를 통해 정제된 설문문항 을 "금산인삼축제" 축제장을 방문한 참여객을 대상으 로 설문조사를 실시했다. 표집설계에 대한 내용과 현황 은 [표 7]과 같다.

\section{표 7. 표집 현황}

\begin{tabular}{|c|c|}
\hline 구 분 & 조 사 내 용 \\
\hline 연구대상 & 금산인삼축제 \\
\hline 표본범위 & 금산인삼축제를 방문한 참여객 \\
\hline 표본추출방법 & 편의추출방법 \\
\hline 조사기간 & 2012. 9. $14 \sim 2012.9 .23$ (10일간) \\
\hline 표본의 크기 & $\begin{array}{l}\text { 총 유효표본: } 277 \text { 부 } \\
\text { - 총 배포된 설문지 수: } 300 \text { 부 } \\
\text { - 총 회수된 설문지 수: } 277 \text { 부 } \\
\text { - 총 회수율: } 92 \%\end{array}$ \\
\hline
\end{tabular}


표 8. 개념적 정의 및 측정도구의 출처

\begin{tabular}{|c|c|c|c|}
\hline 구성 개념 & 개념적 정의 & 측정항목 & $\begin{array}{c}\text { 측정 } \\
\text { 도구의 출처 }\end{array}$ \\
\hline 의례성 & $\begin{array}{l}\text { 공동체 소속의 욕구와 의식함양, 심리적 안정감, } \\
\text { 정화감의 정도 }\end{array}$ & $\begin{array}{l}\text { 1. 의례의 참여로 소속감을 가지게 되었다. } \\
\text { 2. 의례의 참여로 공동체 의식을 느꼈다. } \\
\text { 3. 의례의 참여로 사회적 갈등이 해소되었다. } \\
\text { 4. 의례의 참여로 심리적으로 안정되었다. } \\
\text { 5. 의례의 참여로 마음이 정화되었다. }\end{array}$ & $\begin{array}{l}\text { 척도 개발: } \\
\text { 5문항 }\end{array}$ \\
\hline 체험성 & $\begin{array}{l}\text { 일탈감과 대인교류감, 모험감, 지적 욕구 충족, } \\
\text { 이색적인 창조활동의 정도 }\end{array}$ & $\begin{array}{l}\text { 1. 인삼축제에 참여해서 기분이 좋아졌다. } \\
\text { 2. 인삼축제를 통해 새로움을 느꼈다. } \\
\text { 3. 인삼축제를 통해 일상탈출의 해방감을 느꼈다. } \\
\text { 4. 인삼축제에 참여해서 재미를 느꼈다. } \\
\text { 5. 인삼축제를 통해 호기심을 느꼈다. } \\
\text { 6. 인삼축제를 통해 배움의 기쁨을 느꼈다. }\end{array}$ & $\begin{array}{l}\text { 척도 개발: } \\
\text { 6문항 }\end{array}$ \\
\hline 전시성 & $\begin{array}{l}\text { 전시장의 안정감, 쾌적성, 신기함과 호기심, } \\
\text { 자료를 통해 신기함과 호기심을 불러일으키는 정 } \\
\text { 도 }\end{array}$ & $\begin{array}{l}\text { 1. 전시관이 생동감 있게 잘 꾸며져 있다. } \\
\text { 2. 전시푹의 전시의도가 잘 전달되었다. } \\
\text { 3. 전시관 관함을 통해 많이 학습에 도움이 되었다. } \\
\text { 4. 전시관 관람으로 호기심이 충족되었다. } \\
\text { 5. 전시를 통해 축제주제가 잘 드러나고 있다. } \\
\text { 6. 전시가 축제와 조화를 잘 이루었다. }\end{array}$ & $\begin{array}{l}\text { 척도 개발: } \\
\text { 6문항 }\end{array}$ \\
\hline 판매성 & $\begin{array}{l}\text { 점포분위기, 축제 상품의 레이아웃, 축제 참여객 } \\
\text { 의 흥미를 돋우고 친근감이 있게 소비자를 맞이하 } \\
\text { 는 정도 }\end{array}$ & $\begin{array}{l}\text { 1. 축제 판매장에 다양한 상품이 구비되어 있다. } \\
\text { 2. 축제앙에서 판매되는 상품가격에 만족하였다. } \\
\text { 3. 인삼제품이 잘 진열되어 있다. } \\
\text { 4. 축제장에서 판매되는 상품이 구매력이 있다. } \\
\text { 5. 축제상품 판매점 이용이 편리하였다. } \\
\text { 6. 축제상품 쇼핑하기가 편안하였다. }\end{array}$ & $\begin{array}{l}\text { 척도 개발: } \\
\text { 6문항 }\end{array}$ \\
\hline 교육성 & $\begin{array}{l}\text { 강의의 수준과 강사의 의사소통, 강의의 적절성과 } \\
\text { 수강생이 강의에 충실한 정도 }\end{array}$ & $\begin{array}{l}\text { 1. 세미나 내용의 수준이 적절하였다. } \\
\text { 2. 축제주제와 알맞은 세미나를 하였다. } \\
\text { 3. 강사의 열정을 느낄 수 있었다. } \\
\text { 4. 참여자의 열의를 느낄 수 있었다. } \\
\text { 5. 세미나를 통해 지적 만족을 느낄 수 있었다. }\end{array}$ & $\begin{array}{l}\text { 척도 개발: } \\
\text { 5문항 }\end{array}$ \\
\hline 경연성 & $\begin{array}{l}\text { 정해진 규칙 안에서 참여자의 의지가 작동하여 } \\
\text { 최선을 다하여 승리의 열망 정도 }\end{array}$ & $\begin{array}{l}\text { 1. 인삼축제 경연자들이 규칙을 잘 지켰다. } \\
\text { 2. 인삼축제 경연 관람이 재미있었다. } \\
\text { 3. 인삼축제 경연을 통해 긴장감을 느꼈다. } \\
\text { 4. 인삼축제 경연을 통해 대리만족을 느꼈다. } \\
\text { 5. 인삼축제 경연에서 승리의 열정을 느낄 수 있었다. }\end{array}$ & $\begin{array}{l}\text { 척도 개발: } \\
\text { 5문항 }\end{array}$ \\
\hline 공연성 & $\begin{array}{l}\text { 공연물의 우수성과 명성, 즐거움, 기분전환, 생생 } \\
\text { 한 체험, 정신적 만족감, 문화적 생활수준의 향상 } \\
\text { 을 느낄 수 있는 정도 }\end{array}$ & $\begin{array}{l}\text { 1. 인삼축제 공연물의 우수성을 느낄 수 있었다. } \\
\text { 2. 인삼축제 공연물의 생동감을 느낄 수 있었다. } \\
\text { 3. 인삼축제 공연을 보고 문화적 생활수준이 향상됨을 느꼈다. } \\
\text { 4. 인삼축제 공연물을 관람한 청중들의 감동을 느낄 수 있었다. } \\
\text { 5. 인삼축제 공연관람으로 기분전환이 되었다. }\end{array}$ & $\begin{array}{l}\text { 척도 개발: } \\
\text { 5문항 }\end{array}$ \\
\hline $\begin{array}{l}\text { 축제 } \\
\text { 몰입 }\end{array}$ & $\begin{array}{l}\text { 자발적 참여와 자의식 상실, 환경의 통제감, 체험 } \\
\text { 과제의 수준과 시간감각의 왜곡의 정도 }\end{array}$ & $\begin{array}{l}\text { 1. 축제를 체험하는 동안 시간 가는 줄 몰랐다. } \\
\text { 2. 축제프로그램은 내가 수행하기에 적절한 수준이었다. } \\
\text { 3. 축제를 체험하는 동안 주변 사람들을 의식하지 않았다. } \\
\text { 4. 축제프로그램에 내 자신이 푹 빠졌다. } \\
\text { 5. 축제프로그램에 자발적으로 참여하였다. }\end{array}$ & $\begin{array}{c}\text { 박근수, 2006: } \\
5 \text { 문항 }\end{array}$ \\
\hline $\begin{array}{l}\text { 축제 } \\
\text { 만족 }\end{array}$ & $\begin{array}{l}\text { 축제 유익성과 편의시설, 홍보안내, 쇼핑과 음식, } \\
\text { 축제운영과 서비스의 만족의 정도 }\end{array}$ & $\begin{array}{l}\text { 1. 축제콘텐츠(행사내용)가 유익하였다. } \\
\text { 2. 축제 편의시설에 만족하였다. } \\
\text { 3. 축제의 홍보안내에 만족하였다. } \\
\text { 4. 축제 쇼핑과 음식에 만족하였다. } \\
\text { 5. 축제 운영에 만족하였다. } \\
\text { 6. 축제안내요원들의 서비스에 만족하였다. }\end{array}$ & $\begin{array}{c}\text { 김선희, } 2007: \\
\text { 6문항 }\end{array}$ \\
\hline $\begin{array}{l}\text { 행동 } \\
\text { 의도 }\end{array}$ & $\begin{array}{l}\text { 축제의 재방문, 추천, 긍정적 구전과 우선적 참여 } \\
\text { 의 정도 }\end{array}$ & $\begin{array}{l}\text { 1. 다음 축제에 재방문 하겠다. } \\
\text { 2. 주변사람들에게 축제를 추천하겠다. } \\
\text { 3. 주변사람들에게 축제를 긍정적으로 이야기 하겠다. } \\
\text { 4. 다른 축제보다 우선적으로 참여하겠다. }\end{array}$ & $\begin{array}{l}\text { 오선영 - } \\
\text { 강해상, } 2011: \\
\quad \text { 4문항 }\end{array}$ \\
\hline
\end{tabular}


분석방법은 자료의 일반적 특성을 파악하기 위한 빈 도분석, 개념의 타당성 평가를 위한 요인분석, 신뢰도 측정을 위한 Cronbach's alpha test와 구조방정식을 통 한 확인적 요인분석과 연구 가설검증을 위한 경로분석 에 의하여 수행되었다. 본 연구의 연구가설을 검증하기 위한 경로분석에서 연구모형과 수집 된 자료의 적합도 검증은 Chi-square와 GFI, AGFI, IFI, TLI, CFI, RMSEA 등의 공분산구조방정식 적합도 지수를 기준으 로 판단하였다. 본 연구에서 수집한 데이터를 분석하기 위해 SPSS 18.0과 AMOS 18.0 통계프로그램이 활용되 었다.

\section{3. 개념적 정의 및 측정방법}

본 연구모형의 관계구조를 파악하기 위한 전체 개념 요인들에 대한 개념적 정의는 [표 8]과 같다.

의례성은 “공동체 소속의 욕구와 의식함양, 심리적 안정감, 정화감의 정도”이고, 체험성은 “일탈감과 대인 교류감, 모험감, 지적 욕구 충족, 이색적인 창조활동의 정도”이다. 그리고 전시성은 “전시장의 안정감, 쾌적성, 신기함과 호기심, 자료를 통해 신기함과 호기심을 불러 일으키는 정도”이고, 판매성은 “점포분위기, 축제 상품 의 레이아웃, 축제 참여객의 흥미를 돋우고 친근감이 있게 소비자를 맞이하는 정도"이며 교육성은 “강의의 수준과 강사의 의사소통, 강의의 적절성과 수강생이 강 의에 충실한 정도”이다. 경연성은 “정해진 규칙 안에서 참여자의 의지가 작동하여 최선을 다하여 승리의 열망 정도”이고 공연성은 “공연물의 우수성과 명성, 즐거움, 기분전환, 생생한 체험, 정신적 만족감, 문화적 생활수 준의 향상을 느낄 수 있는 정도”이다. 축제몰입은 “자발 적 참여와 자의식 상실, 환경의 통제감, 체험과제의 수 준과 시간감각의 왜곡의 정도”이고 축제만족은 “축제 유형성과 편의시설, 홍보안내, 쇼핑과 음식, 축제운영과 서비스의 만족의 정도”이다. 그리고 행동의도는 “축제 의 재방문, 추천, 긍정적 구전과 우선적 참여의 정도”이 다.

인구 통계적 변수 항목은 성별, 연령, 직업, 소득 등 6 가지 항목으로 측정되었다. 그리고 축제 콘텐츠품질의 구성개념에 대한 측정은 척도개발에 의한 의례성 5 문
항, 체험성 6 문항, 전시성 6 문항, 판매성 6 문항, 교육성 5 문항, 경연성 5 문항, 공연성 5 문항으로 구성하였고, 결 과변수 구성개념에 대한 측정은 축제몰입 5 문항, 축제 만족 6 문항, 행동의도 4 문항으로 구성하였다. 그러나 본 연구의 원활한 실증분석을 위해 분석에 용이하도록 항 목을 축소하였다. 축소된 문항은 의례성 4 문항, 체험성 4 문항, 전시성 4 문항, 판매성 4 문항, 교육성 4 문항, 경연 성 4 문항, 공연성 4 문항, 축제몰입 4 문항, 축제만족 4 문 항, 행동의도 4 문항으로 실증분석을 실시하였다.

\section{IV. 실증 분석}

\section{1. 표본의 인구통계학적 특성}

본 연구의 인구 통계학적 특성은 남자가 $39.7 \%$ 이고 여자가 $59.6 \%$ 이다. 그리고 연령대는 20 대 이하가 $50 \%$ 정도이고 나머지 30 50대가 고른 분포를 보여주고 있 다. 거주 지역은 금산군 지역주민이 $21.7 \%$ 이고 충남의 인근 시군에서 $28 \%$ 이며 나머지는 충남외 기타지역에 서 방문한 참여객이 $49.5 \%$ 이다[표 9].

\section{표 9. 인구통계학적 특성}

\begin{tabular}{|c|l|}
\hline 특 성 & \multicolumn{1}{|c|}{ 범주 및 빈도(비율) } \\
\hline 성별 & 남(39.7), 여(59.6) \\
\hline 연령 & $\begin{array}{l}\text { 10대(27.1), 20대(25.6), 30대(17.0), 40대(15.5), } 50 \\
\text { 대(13.7), 60대 이상(1.1) }\end{array}$ \\
\hline 거주지역 & 금산군(21.7), 충남(28.9), 충남외 기타지역(49.5) \\
\hline 직업 & $\begin{array}{l}\text { 학생(45.5), 주부(16.2), 회사원(18.1), 공무원(3.2), 전문 } \\
\text { 직(7.2), 자영업(9.7) }\end{array}$ \\
\hline 월소득 & $\begin{array}{l}\text { 81만원 130만원(54.2), 131만원 200만원(13.0), } \\
\text { 201만원 350만원(17.7), 351만원 이상(15.2) }\end{array}$ \\
\hline 학력 & $\begin{array}{l}\text { 중졸이하(19.9), 고졸이하(22.4) 대학재학(19.9) 대학졸 } \\
\text { 업(29.2) 대학원이상(8.7) }\end{array}$ \\
\hline
\end{tabular}

\section{2. 측정도구의 신뢰도 및 타당도 검증}

\section{1 신뢰도 분석}

본 연구에서는 축제 콘텐츠품질의 구성요인인 의례 성, 체험성, 전시성, 판매성, 교육성, 경연성, 공연성과 결과변수인 축제몰입, 축제만족, 행동의도 등의 세부개 념들에 대한 신뢰도를 검증한 결과, 모든 연구요인에 대한 각 크론바하 알파계수(Cronbach's alpha)가 0.870 
이상으로 높은 수준의 내적 일관성을 확보하였다. 구체 적으로 축제 콘텐츠품질의 5 가지 측정항목에 대한 각 a 값은 의례성 0.906(4개 항목), 체험성 0.870(4개 항목), 전시성 0.897 (4개 항목), 판매성 0.895 (4개 항목), 교육성 0.914(4개 항목), 경연성 0.898 (4개 항목), 공연성 0.910(4개 항목)로 분석되었다. 결과변수로 설정한 축제 몰입은 0.871 (4개 항목), 축제만족은 0.902 (4개 항목), 행 동의도는 0.928 (4개 항목)으로 분석되었다.

\section{2 타당성 분석}

연구모형 분석을 위한 측정항목의 타당성을 확보하 기 위해 탐색적 요인분석과 확인적 요인분석을 실시하 였고, 확인적 요인분석과정에서 개념 신뢰도(construct reliability) 및 분산 추출 지수(AVE)를 확인하였다. 또 한, 측정항목의 기준 타당성 확보를 위해 상관분석을 실시하였다.

표 10. 탐색적 요인분석

\begin{tabular}{|c|c|c|c|c|c|c|}
\hline \multicolumn{2}{|c|}{ 요 인 } & 항 목 & 요인 적재량 & 아이겐 값 & 분산률 (\%) & 알파 계수 \\
\hline \multirow{7}{*}{ 외생변수 } & 의례성 & $\begin{array}{l}\text { (1) 소속감을 가지게 되는 정도 } \\
\text { (2) 공동체 의식을 느끼는 정도 } \\
\text { (3) 지역의 소중함 인식 정도 } \\
\text { (4) 마음의 안정감을 가지는 정도 }\end{array}$ & $\begin{array}{l}.806 \\
.828 \\
.800 \\
.788\end{array}$ & 13.749 & 49.105 & .906 \\
\hline & 체험성 & $\begin{array}{l}\text { (1) 새로움을 체험하는 정도 } \\
\text { (2) 재미를 느끼는 정도 } \\
\text { (3) 호기심을 느끼는 정도 } \\
\text { (4) 배움의 기쁨을 느끼는 정도 }\end{array}$ & $\begin{array}{l}.672 \\
.690 \\
.803 \\
.719\end{array}$ & 1.022 & 3.651 & .870 \\
\hline & 전시성 & $\begin{array}{l}\text { (1) 전시품의 생동감 정도 } \\
\text { (2) 전시의도의 전달 정도 } \\
\text { (3) 학습에 도움이 되는 정도 } \\
\text { (4) 축제주제의 반영 정도 }\end{array}$ & $\begin{array}{l}.734 \\
.808 \\
.687 \\
.683\end{array}$ & 1.081 & 3.860 & .897 \\
\hline & 판매성 & $\begin{array}{l}\text { (1) 제품진열의 정도 } \\
\text { (2) 사ㅇㅜㅜㅁ구매력의 정도 } \\
\text { (3) 판매점 이용의 편리성 정도 } \\
\text { (4) 쇼핑의 편리성 정도 }\end{array}$ & $\begin{array}{l}.699 \\
.796 \\
.799 \\
.770\end{array}$ & 2.212 & 7.900 & .895 \\
\hline & 교육성 & $\begin{array}{l}\text { (1) 축제주제와의 관련성 정도 } \\
\text { (2) 강사의 열정 정도 } \\
\text { (3) 참여자의 열의 정도 } \\
\text { (4) 지적 만족 정도 }\end{array}$ & $\begin{array}{l}.701 \\
.763 \\
.795 \\
.748\end{array}$ & 1.684 & 6.016 & .914 \\
\hline & 경연성 & $\begin{array}{l}\text { (1) 경연괄람의 재미 정도 } \\
\text { (2) 긴장감을 느끼는 정도 } \\
\text { (3) 대리만족을 느끼는 정도 } \\
\text { (4) 승리의 열정을 느끼는 정도 }\end{array}$ & $\begin{array}{l}.571 \\
.767 \\
.800 \\
.762\end{array}$ & 1.327 & 4.739 & .898 \\
\hline & 공연성 & $\begin{array}{l}\text { (1) 공연물의 생동감 정도 } \\
\text { (2) 문화수준의 향상 정도 } \\
\text { (3) 청중들이 느끼는 감동의 정도 } \\
\text { (4) 기분전환이 되는 정도 }\end{array}$ & $\begin{array}{l}.670 \\
.706 \\
.716 \\
.637\end{array}$ & 1.026 & 2.700 & .910 \\
\hline \multirow{3}{*}{ 내생변수 } & $\begin{array}{l}\text { 축제 } \\
\text { 몰입 }\end{array}$ & $\begin{array}{l}\text { (1) 프로그ㄹㅐㅐ 수행의 적절한 정도 } \\
\text { (2) 주변사람들의 의식 정도 } \\
\text { (3) 프로그램에 몰입한 정도 } \\
\text { (4) 자발적 참여 정도 }\end{array}$ & $\begin{array}{l}.675 \\
.797 \\
.778 \\
.811\end{array}$ & 1.095 & 9.123 & .871 \\
\hline & $\begin{array}{l}\text { 축제 } \\
\text { 만족 }\end{array}$ & $\begin{array}{l}\text { (1) 축제 편의시설 만족 정도 } \\
\text { (2) 축제 홍보 안내 만족 정도 } \\
\text { (3) 축제 쇼핑과 음식 만족 정도 } \\
\text { (4) 축제 운영 만족 정도 }\end{array}$ & $\begin{array}{l}.785 \\
.844 \\
.798 \\
.737\end{array}$ & 1.178 & 9.814 & .902 \\
\hline & $\begin{array}{l}\text { 행동 } \\
\text { 의도 }\end{array}$ & $\begin{array}{l}\text { (1) 축제의 재방문 의사 정도 } \\
\text { (2) 축제 다른 사람에게 추천 정도 } \\
\text { (3) 축제의 긍정적인 전달 정도 } \\
\text { (4) 다른 축제보다 우선 참여 정도 }\end{array}$ & $\begin{array}{l}.823 \\
.849 \\
.826 \\
.784\end{array}$ & 7.088 & 59.063 & .928 \\
\hline
\end{tabular}


(1) 탐색적 요인분석

연구모형에 사용된 변수의 타당한 개념과 개괄적인 구조를 확인하기 위해 탐색적 요인분석을 실시하였다. 요인 추출은 주성분 분석(PCA)으로 하였고 요인회전 은 직교회전(varimax)으로 분석하였다. 그 결과 [표 10] 에서와 같이 32 문항이 사용되었다.

(2) 확인적 요인분석

본 연구에서 설정한 구조관계를 측정하기 위해 구성 한 설문항목이 경로분석을 실시하기에 타당성을 확보 하고 있는지를 재평가하기 위해 확인적 요인분석을 실
시하였다. 그 결과 [표 11]와 같이 모든 표준화 계수는 $1 \%$ 에서 유의하였고, $\quad X^{2}(693)=1325.548, \quad \mathrm{CMIN} / \mathrm{DF}=$ 1.913, GFI=0.813, AGFI=0.779, IFI=0.933，TLI=0.924, $\mathrm{CFI}=0.933, \mathrm{RMSEA}=0.058$ 등으로 적합도 지수들이 이 상적인 기준치[47]를 어느 정도 충족시키고 있어 모형 은 적합하다고 판단된다.

모형에서 확인된 측정문항들은 각 구성개념에 대해 0.5 이상의 모수추정치를 보여주고 있으며, 각 추정치에 대한 C. R.(t값) 또한 $\mathrm{a}=0.01$ 에서 유의한 2.58 이상으로 나타나 일정 수준 이상의 수렴타당성을 가지고 있는 것 으로 판단할 수 있다. 구성개념에 대한 개념 신뢰도는

\section{표 11. 확인적 요인분석}

\begin{tabular}{|c|c|c|c|c|c|c|c|c|}
\hline \multicolumn{2}{|c|}{ 요 인 } & 항목 & 표준화 계수 & 표준 오차 & C.R (t값) & P-value & 개념 신뢰도 & AVE \\
\hline \multirow{7}{*}{$\begin{array}{l}\text { 외생 } \\
\text { 변수 }\end{array}$} & 의례성 & $\begin{array}{l}\text { (1) } \\
\text { (2) } \\
\text { (3) } \\
\text { (4)* }\end{array}$ & $\begin{array}{l}0.744 \\
0.829 \\
0.852 \\
0.872\end{array}$ & $\begin{array}{c}0.063 \\
0.057 \\
0.062 \\
-\end{array}$ & $\begin{array}{c}14.112 \\
16.787 \\
17.503 \\
-\end{array}$ & $\begin{array}{c}0.000 \\
0.000 \\
0.000 \\
-\end{array}$ & 0.895 & 0.681 \\
\hline & 체험성 & $\begin{array}{l}\text { (1) } \\
\text { (2) } \\
\text { (3) } \\
\text { (4) }\end{array}$ & $\begin{array}{l}0.750 \\
0.844 \\
0.824 \\
0.771 \\
\end{array}$ & $\begin{array}{c}0.070 \\
0.068 \\
- \\
0.071\end{array}$ & $\begin{array}{c}13.745 \\
16.067 \\
- \\
14.242 \\
\end{array}$ & $\begin{array}{c}0.000 \\
0.000 \\
- \\
0.000\end{array}$ & 0.875 & 0.637 \\
\hline & 전시성 & $\begin{array}{l}\text { (1) } \\
\text { (2) } \\
\text { (3) } \\
\text { (4) }\end{array}$ & $\begin{array}{l}0.816 \\
0.884 \\
0.828 \\
0.793\end{array}$ & $\begin{array}{c}- \\
0.060 \\
0.062 \\
0.061\end{array}$ & $\begin{array}{c}- \\
17.399 \\
15.892 \\
14.971\end{array}$ & $\begin{array}{c}- \\
0.000 \\
0.000 \\
0.000\end{array}$ & 0.899 & 0.690 \\
\hline & 판매성 & $\begin{array}{l}\text { (1)* } \\
\text { (2) } \\
\text { (3) } \\
\text { (4) }\end{array}$ & $\begin{array}{l}0.763 \\
0.816 \\
0.886 \\
0.843\end{array}$ & $\begin{array}{c}0.055 \\
0.057 \\
- \\
0.053\end{array}$ & $\begin{array}{c}15.512 \\
17.349 \\
- \\
18.348\end{array}$ & $\begin{array}{c}0.000 \\
0.000 \\
- \\
0.000\end{array}$ & 0.897 & 0.685 \\
\hline & 교육성 & $\begin{array}{l}\text { (1) } \\
\text { (2) } \\
\text { (3) } \\
\text { (4) }^{*}\end{array}$ & $\begin{array}{l}0.854 \\
0.875 \\
0.858 \\
0.821\end{array}$ & $\begin{array}{c}0.065 \\
0.063 \\
0.063 \\
-\end{array}$ & $\begin{array}{c}16.930 \\
17.524 \\
17.042 \\
-\end{array}$ & $\begin{array}{c}0.000 \\
0.000 \\
0.000 \\
-\end{array}$ & 0.913 & 0.726 \\
\hline & 경연성 & $\begin{array}{l}\text { (1) } \\
\text { (2) } \\
\text { (3) } \\
(4)^{*}\end{array}$ & $\begin{array}{l}0.803 \\
0.806 \\
0.908 \\
0.857\end{array}$ & $\begin{array}{c}0.066 \\
0.060 \\
0.052 \\
-\end{array}$ & $\begin{array}{c}13.897 \\
16.514 \\
20.097 \\
-\quad\end{array}$ & $\begin{array}{c}0.000 \\
0.000 \\
0.000 \\
-\end{array}$ & 0.908 & 0.713 \\
\hline & 공연성 & $\begin{array}{l}\text { (1) } \\
\text { (2) } \\
\text { (3) } \\
\text { (4) }\end{array}$ & $\begin{array}{l}0.837 \\
0.877 \\
0.853 \\
0.828\end{array}$ & $\begin{array}{c}0.056 \\
0.058 \\
0.063 \\
-\end{array}$ & $\begin{array}{c}16.791 \\
18.072 \\
17.283 \\
-\end{array}$ & $\begin{array}{c}0.000 \\
0.000 \\
0.000 \\
-\end{array}$ & 0.911 & 0.720 \\
\hline \multirow{3}{*}{$\begin{array}{l}\text { 내생 } \\
\text { 변수 }\end{array}$} & 축제 몰입 & $\begin{array}{l}\text { (1) } \\
\text { (2) } \\
\text { (3) } \\
\text { (4) }^{*}\end{array}$ & $\begin{array}{l}0.833 \\
0.768 \\
0.817 \\
0.741\end{array}$ & $\begin{array}{c}0.079 \\
0.082 \\
0.089 \\
-\end{array}$ & $\begin{array}{c}13.652 \\
12.554 \\
13.652 \\
-\end{array}$ & $\begin{array}{c}0.000 \\
0.000 \\
0.000 \\
-\end{array}$ & 0.869 & 0.625 \\
\hline & 축제 만족 & $\begin{array}{l}\text { (1) } \\
\text { (2) } \\
\text { (3) } \\
\text { (4) }\end{array}$ & $\begin{array}{l}0.802 \\
0.873 \\
0.831 \\
0.844\end{array}$ & $\begin{array}{c}0.055 \\
0.056 \\
0.061 \\
-\end{array}$ & $\begin{array}{c}13.652 \\
12.554 \\
13.385 \\
-\end{array}$ & $\begin{array}{c}0.000 \\
0.000 \\
0.000 \\
-\end{array}$ & 0.904 & 0.702 \\
\hline & 행동 의도 & $\begin{array}{l}\text { (1) } \\
\text { (2) } \\
\text { (3) } \\
\text { (4) }^{*}\end{array}$ & $\begin{array}{l}0.864 \\
0.932 \\
0.905 \\
0.815\end{array}$ & $\begin{array}{c}0.052 \\
0.052 \\
0.053 \\
-\end{array}$ & $\begin{array}{c}17.408 \\
19.546 \\
18.690 \\
-\end{array}$ & $\begin{array}{c}0.000 \\
0.000 \\
0.000 \\
-\end{array}$ & 0.932 & 0.774 \\
\hline
\end{tabular}


0.7 이상이고, AVE값은 0.5 이상을 확보하고 있으므로 개념타당성이 확보된 것으로 판단할 수 있다[48].

(3) 상관분석

본 연구에서 연구모형을 구성하고 있는 축제 콘텐츠 품질의 구성요인과 결과변수의 연관성을 검증하기 위 해 상관관계 분석을 실시했다. 그 각 변수 간 관련성이 가설의 방향과 일치하면서 유의하게 나타나 기준 타당 성이 확보되었다. 또한, 판별 타당성을 검증하기 [표 12] 과 같이 상관계수와 분산추출지수(AVE)를 비교해 본 결과, 모든 구성개념 간의 상관계수와 대각선으로 표시 된 분산추출지수가 각 요인의 상관계수의 제곱, 즉 결 정계수보다 크면 두 요인 사이에는 판별 타당성이 확보 되었다고 할 수 있다[48].

\section{3 연구가설 검증}

구조모형에 대한 적합도 평가와 연구가설을 검증하 기 위하여 연구모형인 축제 콘텐츠품질 요인과 축제몰
입 및 축제만족, 행동의도 간의 관계를 결합하여 구조 모형을 구축하고 분석하였다. 본 연구에서는 최대우도 법(ML)을 통하여 모형의 적합도와 모수를 추정하였으 며, 초기연구모형에 대한 절대적합지수와 증분적합지 수에 의한 평가 결과, $\chi^{2}=1451.144(\mathrm{df}=708, \mathrm{p}=0.000)$, GFI $=0.800$, AGFI $=0.768, \quad \mathrm{IFI}=0.921, \mathrm{TLI}=0.913, \mathrm{CFI}=$ $0.921, \mathrm{RMSEA}=0.062$ 등으로 나타났다. 대부분의 적합 지수가 기준치를 충족하고 있어 모형의 적합성은 적절 하다고 판단된다.

모형의 적합도가 확보된 수정모형의 경로계수는 연 구가설 채택여부에 있어서 더 강력한 근거가 된다. 연 구가설 $\mathrm{H} 1$ 에 해당하는 축제 콘텐츠품질 요인 가운데 체험성과 공연성이 축제몰입에 유의수준 $1 \%$ 이내에서 유의하고, 판매성과 경연성은 $5 \%$ 이내에서 유의한 것 으로 파악되었으며 전시성은 $10 \%$ 이내에서 유의한 영 향을 미치는 것으로 나타났다. 그리나 의례성, 교육성과 축제몰입은 유의하지 않은 것으로 나타났다. 따라서 연 구가설 $\mathrm{H1}$ 에서 세부 가설 $\mathrm{H1b}, \mathrm{Hlc}, \mathrm{H1d}, \mathrm{H1f}, \mathrm{Hlg}$ 는

표 12. 상관관계 및 분산추출지수(AVE)

\begin{tabular}{|c|c|c|c|c|c|c|c|c|c|c|}
\hline 구 분 & 1 & 2 & 3 & 4 & 5 & 6 & 7 & 8 & 9 & 10 \\
\hline 1. 의례성 & $0.681^{*}$ & & & & & & & & & \\
2. 체험성 & $.585^{* *}$ & $0.637^{*}$ & & & & & & & \\
3. 전시성 & $.501^{* *}$ & $.631^{* *}$ & $0.690^{*}$ & & & & & & \\
4. 판매성 & $.350^{* *}$ & $.540^{* *}$ & $.616^{* *}$ & $0.685^{*}$ & & & & & \\
5. 교육성 & $.477^{* *}$ & $.544^{* *}$ & $.648^{* *}$ & $.600^{* *}$ & $0.726^{*}$ & & & & \\
6. 경연성 & $.534^{* *}$ & $.571^{* *}$ & $.539^{* *}$ & $.544^{* *}$ & $.612^{* *}$ & $0.713^{*}$ & & & \\
7. 공연성 & $.526^{* *}$ & $.597^{* *}$ & $.638^{* *}$ & $.617^{* *}$ & $.650^{* *}$ & $.755^{* *}$ & $0.720^{*}$ & & & \\
8. 축제몰입 & $.449^{* *}$ & $.600^{* *}$ & $.537^{* *}$ & $.565^{* *}$ & $.521^{* *}$ & $.620^{* *}$ & $.663^{* *}$ & $0.625^{*}$ & \\
9. 축제만족 & $.464^{* *}$ & $.574^{* *}$ & $.623^{* *}$ & $.611^{* *}$ & $.624^{* *}$ & $.622^{* *}$ & $.702^{* *}$ & $.633^{* *}$ & $0.702^{*}$ & \\
10. 행동의도 & $.442^{* *}$ & $.519^{* *}$ & $.599^{* *}$ & $.485^{* *}$ & $.583^{* *}$ & $.633^{* *}$ & $.680^{* *}$ & $.627^{* *}$ & $.661^{* *}$ & $0.774^{*}$ \\
\hline
\end{tabular}

**. 상관계수는0.01 수준(양쪽)에서 유의함. *대각선 굵은 글씨는 분산 추출값(AVE)

표 13. 연구모형 검증의 결과

\begin{tabular}{|c|c|c|c|c|c|c|c|}
\hline \multirow{2}{*}{$\begin{array}{l}\text { 연구 } \\
\text { 가설 }\end{array}$} & \multirow{2}{*}{$\begin{array}{l}\text { 세부 } \\
\text { 가설 }\end{array}$} & \multirow{2}{*}{ 경 로 } & \multicolumn{4}{|c|}{ 분석결과 } & \multirow{2}{*}{$\begin{array}{c}\text { 가설검증의 종합결과 } \\
\text { 가설채택 }\end{array}$} \\
\hline & & & 경로계수 & 표준오차 & $\mathrm{CR}$ (t값) & $\mathrm{P}$ 값 & \\
\hline \multirow{7}{*}{$\mathrm{H} 1$} & $\mathrm{H} 1 \mathrm{a}$ & 의례성 $\rightarrow$ 축제몰입 & -0.005 & 0.052 & -0.073 & 0.942 & 기각 \\
\hline & $\mathrm{H} 1 \mathrm{~b}$ & 체험성 $\rightarrow$ 축제몰입 & 0.264 & 0.076 & 3.300 & 0.000 & 채택 \\
\hline & $\mathrm{H} 1 \mathrm{c}$ & 전시성 $\rightarrow$ 축제몰입 & 0.043 & 0.071 & 0.541 & 0.588 & 채택 \\
\hline & $\mathrm{H} 1 \mathrm{~d}$ & 판매성 $\rightarrow$ 축제몰입 & 0.176 & 0.060 & 2.538 & 0.011 & 채택 \\
\hline & $\mathrm{H} 1 \mathrm{e}$ & 교육성 $\rightarrow$ 축제몰입 & -0.011 & 0.073 & -0.157 & 0.876 & 기각 \\
\hline & $\mathrm{H} 1 \mathrm{f}$ & 경연성 $\rightarrow$ 축제몰입 & 0.164 & 0.073 & 1.966 & 0.049 & 채택 \\
\hline & $\mathrm{H} 1 \mathrm{~g}$ & 공연성 $\rightarrow$ 축제몰입 & 0.359 & 0.095 & 3.609 & 0.000 & 채택 \\
\hline $\mathrm{H} 2$ & - & 축제몰입 $\rightarrow$ 축제만족 & 0.824 & 0.080 & 11.309 & 0.000 & 채택 \\
\hline $\mathrm{H} 3$ & - & 축제만족 $\rightarrow$ 행동의도 & 0.748 & 0.069 & 11.907 & 0.000 & 채택 \\
\hline
\end{tabular}


채택되었고 H1a, H1e는 기각 되었다.

연구가설 $\mathrm{H} 2$ 에 해당하는 축제몰입과 축제만족은 유 의수준 $1 \%$ 이내에서 영향을 미치고 있어 가설이 채택 되었다. 그리고 연구가설 $\mathrm{H} 3$ 에 해당하는 축제만족 요 인과 행동의도 간에도 유의수준 $1 \%$ 이내에서 영향을 미치고 있어 가설이 채택되었다. 따라서 연구가설 검증 의 종합적인 결과는 [표 13]에 제시하였다.

\section{V. 결 론}

\section{1. 연구결과의 요약 및 시사점}

본 연구는 지속가능한 축제품질 척도 개발 가운데 축 제의 콘텐츠품질 척도를 개발하여 결과변수인 축제몰 입과 축제만족, 행동의도 간의 영향관계를 실증적 검증 하였다. 기존의 선행연구가 대부분 축제의 품질을 평가 할 때 축제의 복잡한 특성을 고려하지 않은 채 하나의 범주 내에서 평가 해왔으나 본 연구자는 축제의 품질 평가를 축제 기초품질, 축제 콘텐츠품질, 축제 서비스품 질 등 3 개의 범주로 나누어 평가하고 있다. 이 가운데 본 연구에서 개발한 축제 콘텐츠품질의 척도는 축제의 생산자와 소비자를 매개하고 축제의 참여객을 유인하 는 수단일 뿐만 아니라 축제의 속성인 축제 콘텐츠를 평가할 수 있는 축제의 품질 측정의 핵심이다.

본 연구에서는 국가지정 축제인 문화관광축제 45 개 를 대상으로 축제콘텐츠를 분석한 결과 7 개의 카테고 리로 분류하여 축제콘텐츠의 구성요인로 설정하였고 각 구성요인에 대한 문헌연구를 통해 측정변수를 도출 하였다. 이렇게 도출된 구성요인이 축제몰입, 축제만족, 행동의도 간에 어떠한 영향을 미치는지를 파악하는 데 연구의 초점을 두었다.

본 연구의 실증연구 대상 축제는 2012년 문화체육관 광부 지정 최우수축제로 지정된 “금산인삼축제”에 참 여한 방문객을 조사 대상으로 총 277 부의 유효 표본을 분석에 사용하였다. 연구에서 설정한 연구목적과 연구 가설을 중심으로 연구결과를 정리하고, 이를 통하여 얻 은 학술적 시사점을 집약하면 다음과 같다.

첫째, 본 연구에서 축제 콘텐츠품질 요인으로 채택한
체험성, 전시성, 판매성, 경연성, 공연성은 공통적으로 축제몰입에 정(+)의 영향을 미치는 것으로 나타났다. 즉 새로움의 체험, 재미, 호기심, 배움의 기쁨을 느끼는 정도와 전시품의 생동감, 전시의도 전달, 학습 도움, 축 제주제 반영 정도에서는 긍정적인 결과가 나타났다. 상 품의 구매력, 판매장 이용, 쇼핑의 편리성의 정도와 경 연관람의 재미, 긴장감, 대리만족, 승리의 열정을 느끼 는 정도 그리고 공연을 통해 생동감, 감동, 기분전환, 문 화수준이 향상되었음을 느낀 것으로 나타났다.

그러나 의례성과 교육성은 정(+)의 영향을 미치지 않 는 것으로 나타나 공동체 소속감, 의식, 지역의 소중함, 마음의 안정감에 대한 부정적인 것으로 나타났고 강의 내용의 축제주제 관련성, 지적 만족, 강사와 참여자의 열정도 부정적인 것으로 나타났다. 이와 같은 결과는 금산인삼축제장의 접근성과 날짜별로 진행되는 콘텐츠 의 참여성과 관련성이 있는 것으로 보인다. 금산인삼축 제에서 전시성이 영향력이 낮게 나타난 것은 전시장이 축제를 위해 만든 전시공간이 아니라 상설 전시장으로 금산군에 방문한 방문객이면 관람 경험이 있는 경우가 많기 때문에 전시의 새로움을 느끼지 못하는 것과 축제 동선의 문제인 것으로 판단된다. 한편, 축제의례와 축제 나 축제관련 산업의 세미나는 축제기간 동안 매일 열리 는 것이 아니기 때문에 참여가 불가능한 축제 참여객이 평가하기에는 무리인 것으로 판단된다.

둘째, 축제몰입이 축제만족에 정(+)의 영향을 미치는 것으로 나타났다. 즉 축제에 대해서 느끼는 프로그램 수행의 적절성, 주변의식, 몰입, 자발적 참여 정도가 축 제 유익성과 편의시설, 홍보안내, 쇼핑과 음식, 축제운 영과 서비스의 만족의 정도에 직접적인 영향요인으로 작용하고 있음을 파악할 수 있다.

셋째, 축제만족이 행동의도에 $(+)$ 의 영향을 미치는 것으로 나타났다. 즉 축제 편의시설, 홍보안내, 쇼핑과 음식, 축제운영의 만족의 정도가 축제의 재방문, 추천, 긍정적 구전과 우선적 참여의 정도에 영향을 미친다는 유의한 결과를 보여주고 있다.

이와 같은 연구결과에 비추어 본 연구가 갖는 실용적 시사점은 다음과 같다.

첫째, 지금까지 대부분의 축제품질의 연구는 $\mathrm{PZB}$ 의 
SERVQUAL을 적용한 연구이거나 축제의 속성을 통한 축제품질 측정이 논의되어 왔으나 본 연구자는 축제의 실무적 관점에서 3 가지 범주로 나누어 연구를 진행하 고 있으며 그 가운데 하나의 범주인 축제 콘텐츠품질의 척도를 개발하여 실증분석을 통해 유의한 결과를 도출 하여 축제 콘텐츠품질 측정의 새로운 기준을 마련하였 다. 이로써 축제콘텐츠를 보다 객관적으로 평가하기 위 한 세분화된 축제품질 측정의 토대를 마련하였다.

둘째, 지역축제의 성공적인 연행을 위해서는 축제콘 텐츠의 구성요인인 의례성, 체험성, 전시성, 판매성, 교 육성, 경연성, 공연성이 중요한 평가요인으로 확인되었 다. 축제콘텐츠의 구성요인에 대한 품질을 확보하여야 만 축제 참여객이 축제에 몰입하게 되고 축제몰입을 통 한 축제만족도가 제고되며 이는 행동의도로 이어져 재 방문과 추천을 하게 된다는 것이다.

\section{2. 연구의 한계 및 향후 연구}

이상과 같은 연구의 의미에도 불구하고 본 연구가 갖 는 한계점 및 앞으로 연구방향에 대해 제안하면 다음과 같다.

첫째, 본 연구에서 축제 콘텐츠품질의 구성요인을 의 례성, 체험성, 전시성, 판매성, 교육성, 경연성, 공연성 등 7 가지 요인을 도출하였다. 여기서 도출된 구성요인 하나하나에 대한 심도 있는 추가적인 연구를 진행할 필 요가 있다.

둘째, 본 연구에서 도출된 축제 콘텐츠품질의 7 가지 구성요인 가운데 의례성과 교육성에 대한 측정은 축제 의례와 축제 세미나가 열리는 현장에서 측정하여 실증 연구에 반영할 필요가 있다.

향후 본 연구자는 축제 기초품질(BASICQUAL)과 축제 콘텐츠품질(CONTSQUAL) 척도 개발에 이어 SERVQUAL을 적용한 축제 서비스품질의 실무적 적용 과 평가에 대한 연구(F-SERVQUAL)를 실시하여 지속 가능한 지역축제의 품질척도(FESTQUAL)를 완성하고 자 한다.

\section{참 고 문 헌}

[1] 이경모, “전통문화축제 이벤트프로그램에 관한 연 구", 이벤트컨벤션연구, 제2권, 제2호, pp.43-59, 2006.

[2] Johan Huizainga, Homo Ludens, Harlem, 1987.

[3] 문화관광부, 문화관광축제 변화와 성과, 문화관광 부, 2007.

[4] 지진호, "문화관광축제의 관광매력성 제고방안에 관한 연구", 한국관광학회 학술대회 발표논문집, pp.27-38, 2006.

[5] 김창수, 박종진, “지역축제의 핵심프로그램 서비 스품질이 방문객 행동의도에 미치는 영향 - 예약 유형 역할 분석을 중심으로 -", 관광경영연구, 제 14권, 제3호, pp.49-68, 2010.

[6] D. Getz, Event Management and Event Tourism, New York: Cognizant Communication Corporation, 1997.

[7] 이경모, "이벤트프로그램 참가동기에 따른 만족 도에 관한 연구”, 경기관광연구, 제7권, pp.79-98, 2003.

[8] 송재일, 손대현, “지역축제 방문자의 자녀교육열 에 따른 행사프로그램 만족차이 연구”, 관광·레저 연구, 제16권, 제2호, pp.71-84, 2004.

[9] 손선미, 체험지향성이 관광축제이벤트 방문의도 에 미치는 영향 연구, 경기대학교 박사학위논문, 2005.

[10] A. Parasuraman, V. A. Zeithaml, and L.Berry, SERVQUAL: A multiple item scale for measuring consumer perception of service quality. Journal of Retailing, Vol.64, No.1, pp.12-40, 1988.

[11] 현용호, 홍경완, “축제 방문동기 집단에 따른 축 제 서비스 품질, 지역 관광 이미지, 재방문 의도간 구조적 관계 고찰-다중 집단 동등분석을 중심으 로-”, 관광연구논총, 제23권, 제1호, pp.169-191, 2011.

[12] 서태양, 부숙진, “축제 서비스품질이 방문객 만 족과 재방문 및 추천의도에 미치는 영향”, 호텔관 
광연구, 제9권, 제2호, pp.114-130, 2007.

[13] 서휘석, 이동기, “지역축제의 서비스 질 구성요 인이 방문객의 만족도에 미치는 영향에 관한 연 구-부안 해넘이 축제를 중심으로-," 한국행정논 집, 제12권, 제3호, pp.581-594, 2000.

[14] 김창수, 박종진, "지역축제의 핵심프로그램 서비 스품질이 방문객 행동의도에 미치는 영향 - 예약 유형 역할 분석을 중심으로 -", 관광경영연구, 제 14권, 제3호, pp.49-68, 2010.

[15] 김희정, 박현우, “전통문화축제 이벤트프로그램 에 관한 연구”, 이벤트컨벤션연구, 제2권, 제2호, pp.43-59, 2006.

[16] 김계섭, “이벤트관광의 프로그램 개선방안”, 관 광학연구, 제18권, 제2호, pp.159-186, 2004.

[17] 조선일보 사설, 하루 3.2 건씩 지역 축제 열리는 '축제공화국', 12 월 25 일 조선일보[사설], 2009.

[18] Catherine Bell, Ritual : perspectives and dimensions, Hanshin University Press., 1997.

[19] E. Pierce, "Tourism's Human Conflicts: Toward more Psychological Approach. Annalsof Tourism Research," Vol.7, No.1, pp.122-136, 1980.

[20] B. H. Schmitt, Experiential Marketing : How to Get Customers to Sense, Feel, Think, Act, Relate, Simon \& Schuster, New York, 1999.

[21] Konikow, How to Participate Prefitably in Trade Show, (Chicago, Dartnell Corp.,), p.129, 1985.

[22] 이정학, 문개성, 김현덕, "자전거전시회 서비스품 질이 참여가치인식 및 전반적 만족도에 미치는 영향”, 체육과학연구, 제20권, 제2호, pp.288-297, 2009.

[23] P. Martineau, "The personality of the retail store," Harvard Business Review, Vol.36(January-February), pp.47-55, 1958.

[24] P. Kotler, G. Armstrong,S. H. Ang, S. M. Leong, C. T. Tan, and O. Yau, Principles of Marketing A Global Perspective, Pretice Hall
Pearson Education South Asia Pte Ltd., 2009.

[25] A. Martensen, L. Gronholdt, J. K. Eskilden, and K. Kristensen, "Measuring Student Oriented Quality in Higher Education: Application of the ECSI Methodology," sinergie rapporti di ricerca, Vol.9, pp.371-383, 2000.

[26] Roger Caillois, Man, play and Games, university of Illionis Press, 2001.

[27] D. W. Johnson and R. Johnson, Cooperation and competition: Theory and research, $\mathrm{MN}$ : Interaction Book Company, 1989.

[28] R. Helmreich, W. Beane, W. Lucker, and J. Spence, "Achievement motivation and scientific attainment," Personality and Social psychology Bulletin, Vol.4, pp.222-226, 1978.

[29] 박정선, “쇼 공연물의 품질이 외국관람객의 만족과 재방문 의도에 미치는 영향 -전문 경영인의 관점에 서-”, 전문경영인연구, 제 14 권, 제3호, pp.163-180, 2011.

[30] Sayre, Shay, Entertainment Marketing \& Communication, Pearson International Edition, 2008.

[31] 권혁인, 주희엽, 김만진, 이현정, 이지애, “공연서 비스에 대한 관람객의 순차적 기대 및 성과와 만 족 간 관계 분석”, 한국콘텐츠학회논문지, 제 11 권, 제2호, pp.287-302, 2011.

[32] 조인희, 정경희, “공연장 서비스 품질이 고객만 족도에 미치는 영향에 관한 연구”, 대한안전경영 과학회지, 제11권, 제1호, pp.155-164, 2009.

[33] 이훈, “축제체험의 개념적 구성모형”, 관광학연 구, 제30권, 제1호, pp.29-46.

[34] M. Csikszentmihalyi, Beyond boredom and anxiety, second printing, San Francisco: Jossey-Bass, 1977.

[35] 박근수, 일몰입에 대한 이해: 한국형 일몰입 척 도 개발 및 타당화와 일몰입의 선행변인 및 결과 변인 규명, 광운대학교 대학원, 박사학위논문, 2006. 
[36] D. A. Baker and J. L. Crompton, "Quality, satisfaction, and behavioral intentions," Annals of Tourism Research, Vol.27, pp.785-804, 2000.

[37] 문성종, “축제 참가동기, 만족도 및 행동의도 구 조관계 분석”, 관광학연구, 제 34 권, 제 8 호, pp.361-384. 2010.

[38] 김선희, "지역축제에 참여한 지역주민과 외지관광 객의 만족도 비교연구: 나주 영산강 문화축제를 중 심으로”, 관광학연구, 제 31 권, 제 1 호, pp.405-420, 2007.

[39] 오선영, 강해상, “축제에서의 체험이 브랜드 태 도, 만족도 및 행동의도에 미치는 영향: 이천쌀 문화축제를 중심으로”, 관광·레저연구, 제 23 권, 제3호, pp.7-22, 2011.

[40] 하광수, 한범수, “주제공원 방문자의 만족과 방문 후 행동의도의 결정요인 -에버랜드를 대상으로 -", 관광학연구, 제25권, 제1호, pp.329-347, 2001.

[41] D. Bowen and J. Clarke, "Reflections on tourist satisfaction research: past, present and future," Journal of Vacation Marketing, Vol.8, No.4, pp.297-308, 2002.

[42] 안대희, 이낙귀, "축제 방문객의 참여동기가 참 여몰입 및 참여만족에 미치는 영향”, 한국콘텐츠 학회논문지, 제9권, 제2호, pp.391-399, 2009.

[43] 강순화, "축제 관여도, 몰입경험 및 지속적 참여 의도간의 관계연구”, 한국자치행정학보, 제 25 권, 제2호, pp.159-176, 2011.

[44] 박정익, 이미혜, “축제 체험프로그램 참여동기가 몰입과 만족, 재방문의도에 미치는 영향”, 이벤트 컨벤션연구, 제7권, 제2호, pp.39-57, 2011.

[45] 민양기, “지역축제의 지각된 품질이 재방문, 구 전에 미치는 영향연구 - 지각된 만족의 매개영향 을 중심으로-”, 여행학연구, 제29권, pp.89-106, 2008.

[46] 허중욱, 박선희, "축제 방문자의 만족과 행동의 도 관계에서 인근 관광지 방문의도의 매개효과”, 동북아관광연구, 제8권, 제1호, pp.81-99, 2012.

[47] 배병렬, Amos 7에 의한 구조방정식 모델링, 도
서출판 청람, 2007.

[48] S. Sharma, Applied multivariate techniques, New York: Wiley, 1995.

[49] 김계수, 구조방정식모형 분석, 한나래아카데미, 2010.

\section{저 자 소 개}

맹 해 영(Hae-Yeong Maeng)

정회원

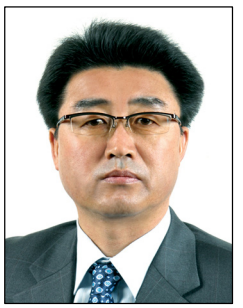

- 1988년 8월 : 경상대학교 국어국 문학과(문학사)

- 2010년 8월 : 한양대학교 엔터테 인먼트학과(엔터테인먼트 석사) - 2010년 9월 현재 : 경상대학 교 경영학과 박사과정 수료

<관심분야> : 지역축제, 엔터테인먼트콘텐츠, 소비자 행동론

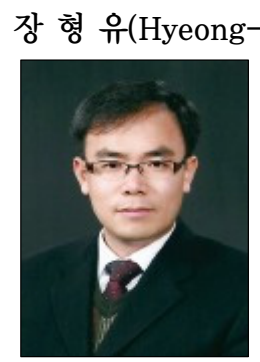

정회원

- 2004년 2월 : 경상대학교 박사

- 2007년 현재 : 대한경영학회, 한국마케팅학회, 인터넷전자상 거래 학회, 한국창업학회 이사

- 2012년 현재 : 경상대학교 경영 학과 교수, 창업교육센터장 <관심분야> : 소비자행동, 마케팅전략, 창업, 지역축제 